The preprint shown in the next pages is accessible according to the license CC-BY-NC-ND. After peer-review, a revised version was accepted for publication and later formatted and published, as available here:

https://www.sciencedirect.com/science/article/pii/S1364032121000617?dgcid=author\#kwrds0010

S. Cristiano, S. Ulgiati, F. Gonella,

Systemic sustainability and resilience assessment of health systems, addressing global societal priorities: Learnings from a top nonprofit hospital in a bioclimatic building in Africa,

Renewable and Sustainable Energy Reviews,

Volume 141,

2021 ,

110765 ,

ISSN 1364-0321,

https://doi.org/10.1016/j.rser.2021.110765.

(https://www.sciencedirect.com/science/article/pii/S1364032121000617)

\title{
Systemic sustainability and resilience assessment of health systems, addressing global societal priorities: learnings from a top nonprofit hospital in a bioclimatic building in Africa
}

Cristiano, S. ${ }^{1,2,3^{*}}$, Ulgiati, S. ${ }^{34}$, Gonella, F. ${ }^{1,2}$

1 = Department of Molecular Sciences and Nanosystems, Università Ca' Foscari Venezia, 30172 Mestre, Venice, Italy.

2 = Research Institute for Complexity, Università Ca' Foscari Venezia, 30123 Venice, Italy.

3 = Department of Science and Technology, Università degli Studi di Napoli "Parthenope", 80143 Naples, Italy.

$4=$ School of Environment, Beijing Normal University, 100875 Beijing, China

*=corresponding author details, silvio.cristiano@unive.it; silvio.cristiano@uniparthenope.it; +390412348595, via Torino 155, Alfa 5.10, 30172 Mestre, Venice, Italy

\begin{abstract}
Health services represent a cornerstone to ensure well-being and human rights everywhere, particularly in deprived areas with limited access to resources. We investigate the resource cost and appropriate use for the implementation of a top-quality hospital in Sudan. An integrated Life-Cycle Assessment and systems-based Emergy Accounting approach is applied to assess its sustainability and resilience. Very few similar studies have addressed civil works so far, even less bioclimatic buildings, while our focus on health systems is an absolute novelty. Particular attention is paid to bioclimatic design in adverse climate and economic conditions, to the humanitarian nongovernmental organisation running the hospital, and to the cutting-edge medical staff and technologies imported from abroad that at the same time allow local practitioners to train in excellence medicine. The system's direct and indirect socio-ecological requirements are expressed as emergy (resource investment) per patient-day, per cardiac surgical operation, per outpatient visit, and per year. From a quantitative viewpoint, these indicators represent a benchmark for improvement scenarios, comparison with new studies in a deserving field, and future investments, driven by effective healthcare policies. They also provide an overview of the efforts required by nature and society to ensure a human right in conditions of scarcity. In addition to the possibility to lower a hospital's environmental impact (sustainability-oriented) and to keep it functioning over time in changing climate, resource, societal, economic, and geo-political scenarios (resilience-oriented), this study leads to original remarks upon societal priorities and upon the challenges of guaranteeing high-quality health systems in an uncertain century.
\end{abstract}

\section{Highlights:}

- A layout and novel indicators are introduced for the evaluation of health systems

- Health provision crucially relies on societal priorities and resource allocation

- Remarkable performances in sustainable resource use are reached in our case study

- The largest fraction of embedded energy lies in medical labour and services

- Savings from a bioclimatic building can further pursued through this approach 


\section{Keywords:}

Systems Thinking; Healthcare; Emergy Accounting; Resilience; Sustainable Design; Bioclimatic building; Africa; Energy poverty; Renewables; Resource use; Ethics; Socio-ecological sustainability.

Word Count: 7,956

\section{List of abbreviations}

$\begin{array}{ll}\text { \%Ren } & \text { Renewable Emergy Percentage } \\ \text { AEI } & \text { Areal Empower Density } \\ \text { ELR } & \text { Environmental Loading Ratio } \\ \text { EMA } & \text { Emergy Accounting } \\ \text { Empd }_{(\mathrm{r})} & \text { Renewable Empower Density } \\ \text { ESI } & \text { Emergy Sustainability Index } \\ \text { EYR } & \text { Emergy Yield Ratio } \\ \text { F } & \text { Imported sources from out of the system } \\ \text { L\&S } & \text { Labour and services } \\ \text { LCA } & \text { Life-Cycle Assessment } \\ \text { N } & \text { Locally available nonrenewable sources } \\ \text { NGO } & \text { Nongovernmental Organisation } \\ \text { p-day } & \text { Patient-day } \\ \text { R } & \text { Locally available renewable sources } \\ \text { SA } & \text { Renewable Support Area } \\ \text { SDG } & \text { Sudanese Pound } \\ \text { sej } & \text { Solar emjoule } \\ \text { seJ } & \text { Solar equivalent joule } \\ \text { U } & \text { Total Emergy input } \\ \text { ULS } & \text { Annual emergy use with labour and services } \\ \text { UEV } & \text { Unit Emergy Value }\end{array}$

\section{Introduction}

After the first warnings in the 1970s, a crescendo of voices is now recognising that the ongoing climate, ecological, economic, socio-political, and health crises have common causes and drivers. A complex system requires a complex, systemic approach. The present coronavirus emergency has further highlighted the criticalities of a closely interconnected world. A period like this, exhibiting more visible crises, calls for our attention on what we cannot give for granted in an uncertain $21^{\text {st }}$ century: a thread can be seen among ecological sustainability, international economics, societal mechanisms, and future resilience to their possible alterations.

In this paper, we address some urgent topics in the global agenda, valid for both the Global South and North: (a) health systems, called to adequately provide a basic right, and the delicate functioning of healthcare facilities; (b) the energy performances of buildings in times of climate change, depleting resources, energy poverty, and rapid urbanisation; (c) the design, assessment, and management - through appropriate tools - of a complex system in a changing world. Multiple international goals [1] are involved; among these: \#3 (good health and well-being), \#7 (affordable and clean energy), and \#13 (climate action).

The organisation, efficiency, and overall sustainability of health systems at all scales have recently drawn new attention due to the Covid-19 pandemic. Precariousness and lack of resources were evidenced worldwide in the reaction towards the coronavirus spread. This has caused even the most advances economies in the world to struggle to meet the a skyrocketing demand for health services [2]. Moreover, this has also led to the necessity to divert the available personnel and equipment from the cure of other pathologies to that of the virus infected, so creating further malfunctioning in medical services and domestic assistance. The Global Risk Report 2020 [3] had warned [4] that: "A recent first-of-its-kind comprehensive assessment of health security and related capabilities across 195 countries found fundamental weaknesses around the world: no country is fully prepared to handle an epidemic or pandemic". If the wealthier regions of Global Northern countries are in difficulty, plights are further aggravated in the South and in other contexts affected by poverty, 
conflicts, forced displacement, severe climate conditions ${ }^{1}$, and higher risks of a zoonotic viral spill, including Africa [5]. This means that a systemic study on how to set up a sustainable health service is strongly needed at all levels, and that important weaknesses may come from a bad use of the resources, independently of their amount and quality. The current pandemic has been recently seen as an opportunity to reconsider the collision between an injust "globalised capitalism and the carving up of continental ecosystems" [7]. In this respect, this work addresses the health services assessment by a more comprehensive socio-ecological point of view such that provided by the systems-based emergy method, able to track direct and indirect resource and information inputs to a given system. Such method has been proposed as a way to "move environmental ethics beyond anthropocentrism" [8]. In particular, a combination of the Life-Cycle Assessment (LCA) and Emergy Accounting (EMA) methods provides complementary perspectives to look at the environmental sustainability of complex systems. The integration and synergic use of these approaches has been claimed by many as a much needed pattern for deeper and more comprehensive understanding. Haberl et al. [9] outline the need for systemic approaches able to bridge natural and social sciences to pursue global sustainability goals, while social and environmental goals imply environmental change as well as an increasing use of biophysical resources (energy, materials, etc.), which are therefore to be accounted for.

Concerning the resources, the access to energy is quite unequal on the planet, although global energy demand keeps increasing [10], and so does - at least for the moment - energy provision. This means that some contexts undergo conditions of so-called energy poverty [11][12]. Scarce access to energy provision is typical of marginal areas of the Global North and, more often, of the South. Here, energy distribution networks are often limited, especially out of the big cities, with energy shortages however possible also in urban contexts. If "regular life" can keep on anyway, and adjust to the current energy availability as per millennial cycles in societies, a crucial aspect of energy poverty is of course related to hospital operations, due to life-saving machineries depending upon electricity, and to the need for adequate indoor temperatures to prevent the diffusion of diseases ${ }^{2}$. This is the case of many African hospitals, whose geographical location in tropical or equatorial areas gives rise to frequent high temperature conditions. The above considerations about energy access also apply to other material resources, such as construction materials, machinery, sanitary items, etc. In this regard, the use of tailored building technologies and materials for local and economic contexts is widely insufficient, with imported solutions not always suiting local requirements. Such extreme contexts can paradoxically "be considered as a laboratory for all the planet", for their facing now those same conditions that the Global North "could be led to face in the next future" [14]. Similarly, we could maintain that hospitals might anticipatorily show that saving valuable, scarce resources is not only crucial for social and environmental concerns, but also for the very durability of basic societal functions, like the one to save human lives.

The combination of outdoor weather conditions, indoor temperature (hence energy) requirements, and suitable insulation through appropriate materials and technologies seems to play a significant role in civil buildings in general, and above all in healthcare structures, especially those located in energy-poor contexts with unfriendly climate conditions. As a response to unstable urban electricity networks ${ }^{3}$, averagely expensive and carbon intensive oil-fuelled generating sets are often employed to ensure the necessarily stable functioning of air conditioning systems as well as all the life-saving biomedical appliances inside operating theatres, intensive care rooms, and even in common wards where basic services such as aided respiration are required. In a transition towards clean energy sources, facilities in temperate and especially tropical areas can exploit one of the most abundant source, i.e., solar radiation, a "democratic" source balancing higher requirements with higher availability [16][17]. Bioclimatic design [18][19][20] and investments on solar-based systems appear therefore as appropriate strategies for the specific energy needs of African hospitals. Parallel to this, solutions aimed at using renewable sources [21] and at providing buildings with passive mitigation to reduce the total energy demand for air conditioning would also appear as suitable for the reduction of both resource and monetary costs [16][22], thus partially making up for the energy poverty. Local, clean, renewable materials (wood, vegetable fibres, etc.) can also play a role in sustainable building construction and furnishing.

In recent years, the sustainability of building design has undergone several assessments, mainly based upon the LCA-based methods [23]. Some of these can be integrated with Building Information Modeling [24][25], especially for the design of plumbing, heating, ventilation and air conditioning, and electrical systems [23]. One of the most used certifications to evaluate supposedly sustainable civil constructions is the

\footnotetext{
${ }^{1}$ About climate risks, pandemics, and health systems' preparedness, see Phillips et al. [5].

${ }^{2}$ Energy access as a pivotal driver to ensure health in emergencies such as the Covid-19 pandemic has been recently addressed [13].

${ }^{3}$ Further information about electricity networks in Sudan and surrounding countries is provided in [15].
} 
Leadership in Energy and Environmental Design suite [26], brought in 1998 by the United States Green Building Council as a voluntary standard. At the regulatory level, we cite the Nearly-Zero Energy Buildings [27][28], for which national accompanying plans have been encouraged in Europe in the past decade. As reported by the International Energy Agency [29], since 2007 an interest has increased for the calculation of the embodied energy [30] in building design [31]). In some cases, e.g., Switzerland, this has entered the public guidelines supporting decision-making for new constructions [32]. However, Braham [33] claims that NearlyZero Energy Buildings offer no much more than an environmental "style", focused on operational energy requirements, and that other important inputs are neglected, such as construction and maintentance ones, in addition to free, unpaid ones such as renewable, environmental inflows. Similarly, although explicitly including many environmental costs, recent voluntary standards would "lack a rigorous metric with which to reconcile the costs and effects of different environmental impacts" [33] . In Braham's view, a similar reconciliation can happen through a sustainability science rooted in systems thinking [35] and based on the emergy (spelled with "m") metrics. This way, it would be possible to account for the entire network of environmental and human work required for a building to be constructed, maintained, and operated, while trying to minimise its impacts. In the light of the crises we are facing, we resort again to Braham [33], suggesting that the notion of sustainability that we can acquire through systems thinking and the emergy approach can help in preventing alternative and maybe more dramatic outcomes, responding to the effects of scarcity. Details about the opportunities of using emergy in architecture and building design are treated by Srinivasan and Moe [36], whose monograph includes a meaningful epigraph by Braham [37], and by Cristiano [38], in addition to theses and dissertations [39][40][41]. The opportunities offered by the enlargement of the analytical boundary compared to the embodied energy and LCA approaches are illustrated, respectively, in Brown and Herendeen [42] and Raugei et al. [43], the latter also expaining the integration between LCA and emergy accounting, which we also use. Through our same approach, very few civil works have been investigated so far. Some authors analysed [44][45][46] or suggested to analyse [47] transport systems and infrastructures, but studies about entire edifices are even fewer, none of which can be anyhow defined as "bioclimatic". Meillaud et al. [48] focused on an academic building using solar energy through a photovoltaic façade. Others analysed some residential units in Canada [49] and an off-grid residence located in an ecovillage of North Carolina, USA [50]. Cristiano and Gonella [16][22][51] compared low-tech vernacular innovation with conventional building technologies, including construction requirements and lifetime savings. Other authors [52] addressed the emergy inputs in the life cycles of key building materials, including recycling options. Similarly, Pulselli et al. [53] analysed some energy and material inputs for building construction, maintenance, and operation ${ }^{5}$. Through the sole Life-Cycle Assessment, hospitals were only partially investigated: in the light of the very nature and analytical boundaries of the LCA approach, industrial processes or alike are more suitable. Some [55][56] focus on the technical aspects of the construction of a hospital, others [57][58] on hospital solid waste disposal or treatment. Further works address more partial processes, such as hospital laundry or medical sharp objects, and are therefore even farther from the aims of the present paper.

To the best knowledge of the authors, except for the above cited doctoral thesis by Cristiano [41], no previous work has ever addressed a complex system such as a hospital in our same terms, encompassing the three aforementioned topics (a), (b), and (c) ${ }^{6,7}$. We apply, from a systems thinking perspective, an LCA-based emergy accounting evaluation to comprehensively and quali-quantitatively assess the sustainability and resilience of a hospital and its related healthcare system ${ }^{8}$. This work may be regarded as a first step to: (i) systemically understand the main requirements, strenghts, and vulnerabilities of health systems and their hospital facilities, especially in a period of dire need of health like this; (ii) learn, from both method and results, how to best address energy-performative building design in a challenging era of scarcity; and (iii) provide an example of systemic design, assessment, and management of a complex system in a complex epoch, undepending of its nature (here, a humanitarian health facility). This study also aims at providing a benchmark for future comparisons, including a possible improvement assessments of the same case study and - above all - extension to the design, rethinking, and assessment of other expectedly long-term sustainable buildings and resilient, long-lasting hospitals.

\footnotetext{
${ }^{4}$ In addition to this, most ratings do not assess a building's post-occupancy performances and rarely refer their calculations to comparable units such as energy consumption per square metre [34].

${ }^{5}$ These studies are part of the extensive use of the emergy approach at micro levels [54].

${ }^{6}$ We report that we are co-authoring a smaller case-study exercise in this direction [59].

${ }^{7}$ Pineo et al. (2020) have recently addressed health issues through systems thinking, yet their causal loop approach is very different from ours, and anyway focused on health in relation to urban planning policies [60].

${ }^{8}$ Pertinent dissertations on a similar assessment, but applied to urban systems, are available in Cristiano et al. [61].
} 


\section{Materials and methods}

\subsection{The Salam Centre for Cardiac Surgery in Khartoum, Sudan}

Our case study is represented by a top-level, nonprofit specialised hospital, designed, built, and run by Italian humanitarian NGO Emergency ${ }^{9}$ : the Salam Centre for Cardiac Surgery in Sudan (Fig. 1). The hospital is located in Soba, $20 \mathrm{~km}$ south of capital city Khartoum (Fig. 2), by the shores of the Blue Nile river. Built between 2004 and 2007 on a lot of land of roughly $40,000 \mathrm{~m}^{2}$, its buildings cover an area of 12,000 $\mathrm{m}^{2}$. Its design as a top-level hospital in the Saharan-Sahelian adverse climate conditions required specific strategies. Outdoor temperatures can reach $50{ }^{\circ} \mathrm{C}$, while operating theatres require $18{ }^{\circ} \mathrm{C}$, and instensive care rooms 24 ${ }^{\circ} \mathrm{C}$ [17]. Design attentions were paid to make the structure sand- and heat-proof [62]. A 60-meter long underground labyrinth-shaped tunnel, inspired by Persian wind towers (badgir) [63] contributes to natural ventilation and cooling (averagely, channelled air is $9{ }^{\circ} \mathrm{C}$ cooler than the outside temperature). The external walls are $60 \mathrm{~cm}$ thick, built with multiple brick layers with insulated air chambers inbetween. The windows are small and equipped with double, sun-screened glasses. The non-built land around the hospital pavillions has been extensively planted with trees and hedges, directly watered from the close river. Following biomimetic principles [64], the porticoes around the main building are screened by panels of intertwined vegetable fibres (from Sudanese saf leaves), locally woven inspired to a traditional Sudanese technique for bed manufacturing. 288 vacuum-sealed solar collectors (covering $900 \mathrm{~m}^{2}$ ), matched to two absorption chillers, help reducing the amount of fuel required to circulate 28,000 cubic metres of cold air every hour. The lowtech innovations for cooling, insulation, and filtration, and their related energy savings are illustrated and discussed in Cristiano and Gonella [16]. They confirm that, against the mainstream cultural colonisation, learning from context-specific vernacular wisdom [65] can yield interesting energy savings [66], or at least mark promising paths in design.

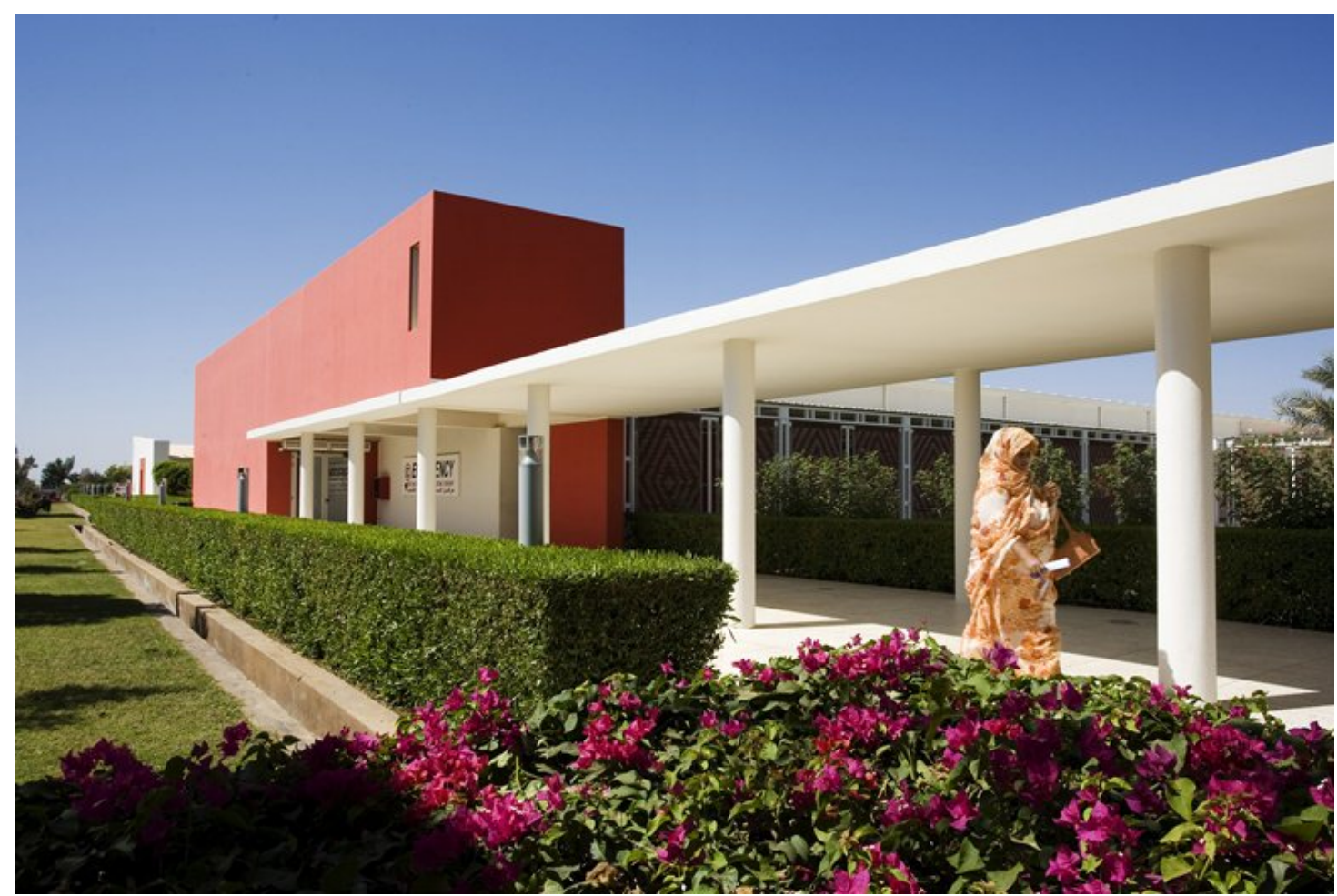

Figure 1 - The Salam Centre: surrounding vegetation, entrance of the wind tunnel, and vegetal panels (photo by M. Bonfanti, courtesy of TAMassociati and Emergency)

\footnotetext{
${ }^{9}$ https://en.emergency.it/ (accessed May 2020]
} 


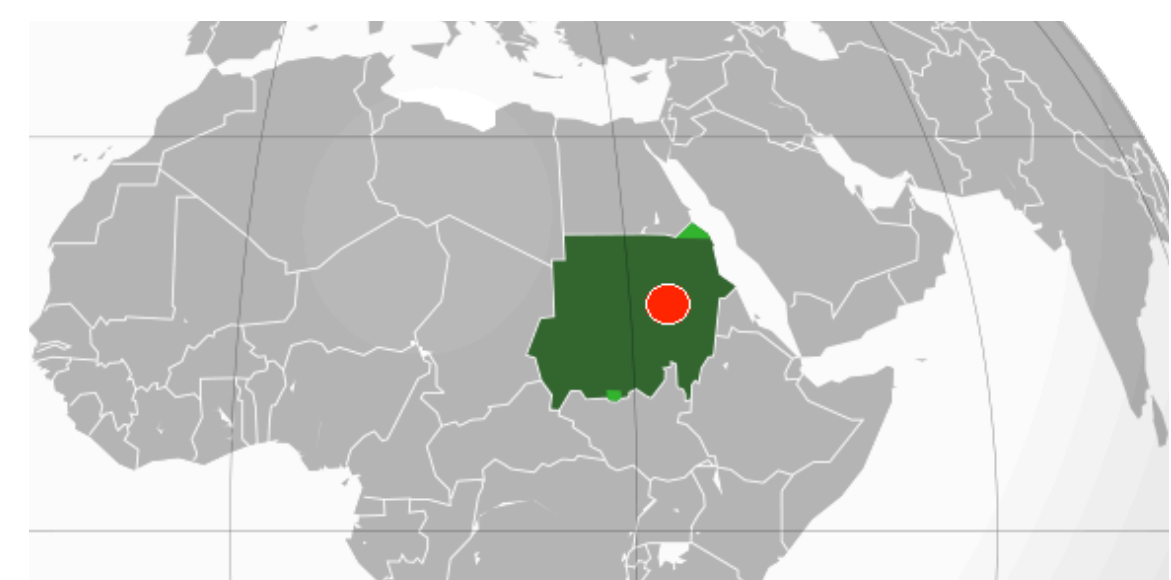

Figure 2 - Location of Khartoum (CC-BY-SA 3.0, Dinamik)

The structures of the Salam Centre include: 3 operating theatres, 15 intensive care unit beds, one sterilisation room, one catheterisation laboratory, reception, outpatients consultation rooms, radiology, ultrasound, laboratory and blood bank, pharmacy, 48-bed ward (including a 16-bed sub-intensive care unit), nurses' room, physiotherapy, recreation room for staff and patients, storage areas, administration and offices, laundry, ironing, kitchen, library, conference and teaching room, children's playroom, cafeteria, guesthouse, and a technical area. The hospital is equipped with biomedical machineries that are accounted for in our study. Most patients go by themselves to the Salam Centre, without been referred by physicians or medical facilities. After an initial triage, patients with known or potential cardiac problems receive further cardiac investigations. Between 2007 and 2018, 75,312 patients were triaged, and 69,996 underwent cardiological examinations; 9,146 were admitted, someone twice or more, for a total of 11,636 admissions; surgeons offered 8,093 operations to 7,676 patients, and 1,382 cath lab procedures. Annual numbers used for our assessment are reported in Table 1.

Table 1. Salam Centre's clinical activities in our reference year

\begin{tabular}{|l|c|}
\hline Outpatients visits (triaged patients) & 5,748 \\
\hline Cardiological visits & 6,619 \\
\hline Cardiac surgical operations & 518 \\
\hline Cath lab procedures & 34 \\
\hline Inpatients per day, average & 44.1 \\
\hline
\end{tabular}

The mean age of operated patients was 26 years. Most of patients had valvular heart diseases, many others congenital heart diseases, and a minority ischemic heart diseases. Although most of them were Sudanese, in the time span at issue patients arrived from 30 different countries. The Salam Centre is the only facility offering free-of-charge, qualified cardiac surgical care in a very large region ${ }^{10}$, covering 11.5 million $\mathrm{km}^{2}$ (i.e., three times the size of Europe), with a population of over 300 million people and with frequent healthcare coverage gaps [67]. The managing NGO promotes a regional health system comprising a network of medical facilities and activities in Sudan and in surrounding countries, so as to ensure adequate screening (especially paediatric) and post-operative follow-up for those coming from far away. When required, the NGO provides free transportation for foreign patients. Relatives who accompany minors are hosted in the hospital's guesthouse. Emergency has ongoing agreements with several ministries of health in the Sub-Saharan region, including the Sudanese one, co-financing the hospital. The present study is mostly based upon both the information provided by the hospital administration. Some data come from original calculations. Anyway, sources and procedures are all specified in the Results section.

\subsection{The emergy method}

Our study is based on the Emergy Accounting (EMA) concept and method. Emergy allows to quantify, through the same unit, all the investments that are required to realise a project or a service - in our case, the

\footnotetext{
${ }^{10}$ Including Sudan, Egypt, Libya, Chad, Central African Republic, Democratic Republic of Congo, Uganda, Kenya, Ethiopia, and Eritrea.
} 
complex system formed by the nonprofit hospital in a purposely designed bioclimatic building. The emergy concept was first introduced by Howard T. Odum [68][69][70][71], sometimes considered as an expansion of the aforementioned embodied energy concept [72]. Emergy is defined as "the available energy of one kind previously used directly or indirectly to generate a service or a product". Through emergy, it is possible to assess the performances of a given system based on a common energy metrics: the solar emjoule (sej), elaborated through solar equivalent exergy, whose unit is the solar equivalent joule (seJ). The emergy requirement per unit of output (energy, matter, labour, information, services, money) is defined as Unit Emergy Value (UEV) and measured in sej/unit (sej/J, sej/g, sej/h, sej/currency, etc.). Unlike other social environmental accounting methods, emergy accounting keeps track of both the natural processes that were required to generate and concentrate resources over time and of the antropic activities to extract, manufacture, and delivery such resources. If compared to the embodied energy approach, the EMA method presents a boundary expansion over space (in that accounts for large scale phenomena that indirectly contribute to the local dynamics), over time (processes for resource generation), and over resource categories (since it also includes natural flows such as solar radiation, deep heat, wind, rain, and gravitational energy) and material flows (like metals and mineral ores) [46]. Moreover, in an EMA assessment also the resources supporting direct labour and services are included (with the latter representing indirect labour). Labour and services carry fractions of the infrastructure, information, and know-how associated with the larger economy in which the investigated system is embedded [73] - something that cannot be disregarded if a comprehensive sustainability evaluation is the goal. These innovative features of EMA provide an added value to the assessment, much beyond and certainly complementing the usual monetary and energy evaluations.

The first steps of an emergy accounting procedure are the definition of the boundaries of the investigated process or system and the drawing of the diagram, using the energy systems language [74]. After these, the flows (energy, matter, etc.) driving the process or system are identified and quantified, usually grouped in categories: $(\mathrm{R})$ local renewable resources, provided for free; $(\mathrm{N})$, locally available nonrenewables; and (F) imported goods from out of the system. All these inputs are then expressed in emergy units after a conversion using suitable UEVs, referring to the same geobiosphere global emergy baseline (GEB, the total renewable emergy driving the geobiosphere in one year). In this paper, the $\mathrm{GEB}_{2016}$ of $1.20 \times 10^{25} \mathrm{seJ} / \mathrm{yr}$ [75].

At the end of an emergy accounting procedure, selected indicators can be calculated suitable for investigating the system at issue [69]. Among these, we calculate the emergy yield ratio (EYR), the environmental loading ratio (ELR), the renewable emergy percentage (\%Ren), the areal empower intensity (AEI), and the emergy sustainability index (ESI). The EYR is the ratio between U, the total emergy output given by $\mathrm{R}+\mathrm{N}+\mathrm{F}$, and what purchased from the economy, $\mathrm{F}$, thus indicating how much the emergy output of a system actually depends on purchased resources, whose emergy is in principle already available at the society level. It therefore addresses the question of how well the environmental resources are used for a given input from the economy, without distinguishing between renewables and nonrenewables. The $E L R=(F+N) / R$ indicator compares what is received from the economy plus local nonrenewables to the emergy coming from local renewables. It indicates in general the level of environmental impact. The Emergy Sustainability Index, $\mathrm{ESI}=\mathrm{EYR} / \mathrm{ELR}$, is an integrated measure of economic yield and environmental performance, and addresses the contribution to the overall support environment per unit load of the local system. By putting together two indicators sensitive to local/nonlocal aspects (EYR) and renewable/nonrenewable ones (ELR), it provides an integrated evaluation of the long-term sustainability. New UEVs and indicators may be then defined for specific case studies, and this is also the case of the system we here investigate. For the calculation of new UEVs, an integration with the LCA method is performed [43][76], based on database Ecoinvent 3.1 [77], also computing the Cumulative Energy Demand [78]. Some UEVs, tailored for a hospital, also emerge as a result of the assessment.

The emergy evaluation is performed by following the usual procedure of first diagramming the system while choosing its boundaries, then creating a comprehensive inventory of the resources directly and indirectly involved in the system setting up and operation, converting them in emergy terms, and finally calculating a set of standard (here, also brand-new) indicators, representing the actual investment. By investement, one means what is provided by outer human economies as well as by the rest of [79] the geobiosphere. Physically, the boundaries of the healthcare system at issue include the entire lot of land where the hospital lies and a portion of the adjacent river, supplying the water-bearing strata underneath the lot. The temporal boundary is one year, i.e., 2015. At the beginning of our study, it represented the most recent year with full and validated data for a reliable assessment. Based on communications with the Emergency $N G O$ staff members as well as on comparison with the decennial data illustrated in section 2.1, that year the hospital operated at the $70 \%$ of its full capacity. As partly specified above, some pertaining activities (screening, administration, public relations, 
patient transportation) are performed out of the gates of the hospital, but are of course still accounted in our analysis. For inputs to stocks lasting longer than one year, allocation is made according to the related lifetime. Clinical records for our reference year are reported in Table 1.

The driving flows of our system are assessed in terms of energy, materials, goods, labour, information, and services, so as to provide detailed information about the requirements of the hospital, including its key inputs, processes, and feedbacks. In addition to standard indicators [69], some novel indicators are specifically designed and calculated to pioneeringly address a health system: the emergy per (cardiac) surgical operation; the emergy per patient-day, referred to inpatients; and the emergy per outpatient visit. This allows to make the emergy accounting more suitable for decision-making in the health sector, since the number of operations, patient-days, and outpatients visits are all part of the management, accounting, and economic languages of health systems.

\section{Results}

\subsection{The hospital system}

The diagram reporting the main stocks and flows of the Salam Centre is shown in Figure 3. Environmental inputs, including renewable sources, enter the system from the left. Granted that all of them are to be accounted for, some of these are specifically exploited in the specific configuration of the system, namely, green areas, solar thermal panel system (with connected chillers), and a natural ventilation and air conditioning by filtration throughout the sand tunnel. Inputs imported from human economies enter from the top. Among such inflows - and this is a peculiar feature of a system involving an NGO (see also [80]) - we can distinguish paid and voluntary labour, and paid and donated services. Inasmuch as a hospital co-funded by an NGO and the Sudanese ministry of health, monetary (i.e., dashed) inflows come from both international donors and through the local government - the Sudanese people. Voluntary work, donated money or services, private and public funding are all activated by the image the hospital shows to the outer world. In fact, the reputation of the NGO is a leverage point for the overall system, crucial for the regulation of flows coming from out of its boundary. Nevertheless, the main operations of the hospital naturally involve patients. For those reading a coloured version of the diagram, the patient cycling is highlighted in red: patients enter the Salam Centre encouraged by screening and health promotion activities and/or attracted by their trust in the hospital - again, by its public image (reputation). Contributions to the hospital's image come from both internal and external press activities and from public relations, in addition to the very quality of the hospital care (professionalism, hygiene and safety, medical success, etc.). 


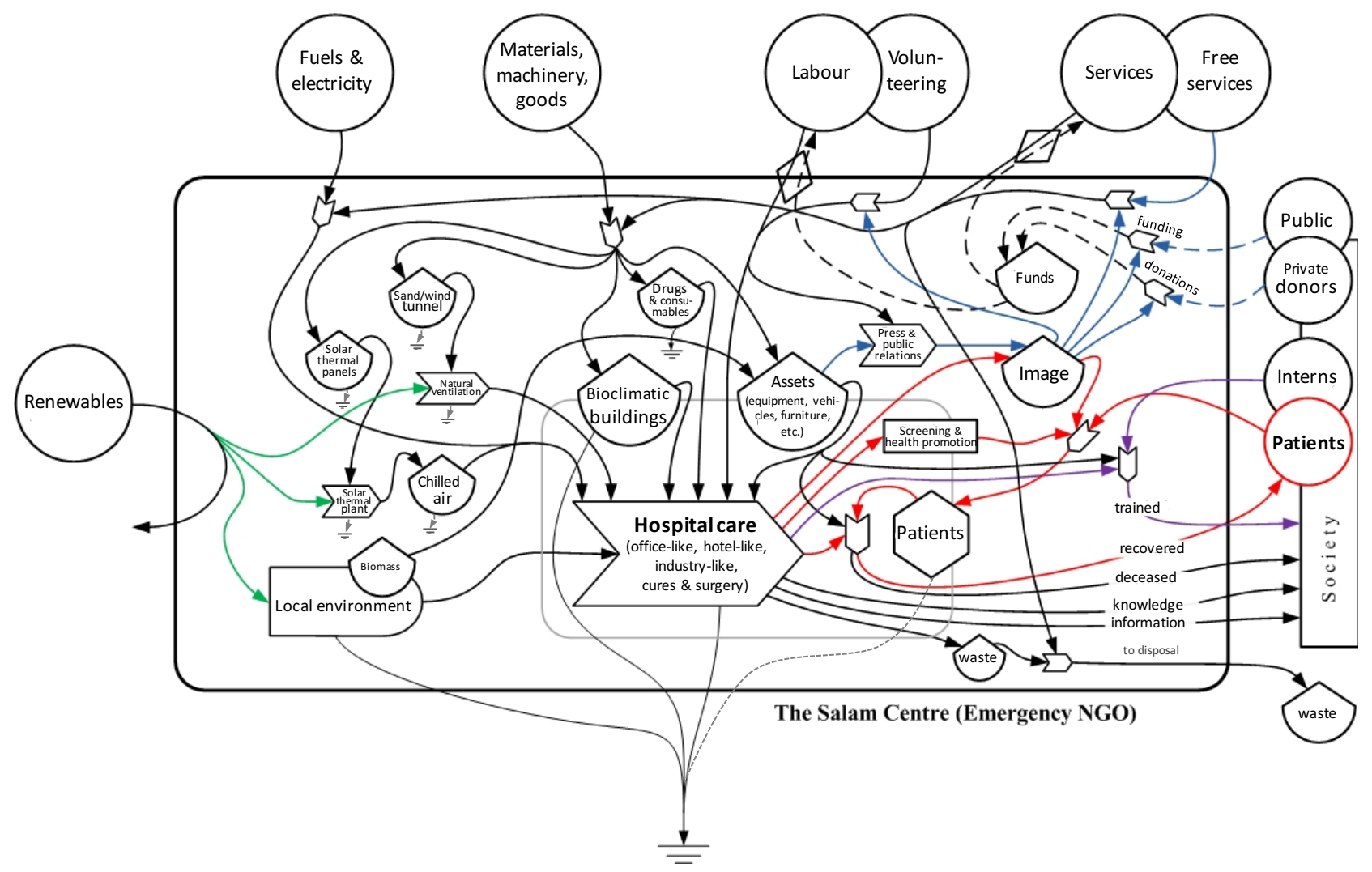

Figure 3 - System diagram of the Salam Centre (after Cristiano \& Gonella [51])

After being cured, most patients usually leave the hospital premises as recovered. This is the main desired output of a system pursuing free-of-charge specialised health provision as its main goal. Side outputs are represented by: (i) the specialised training of local staff (medical doctors, nurses, other medical operators), happening through an agreement for accepting interns from Sudanese medical schools; (ii) knowledge and information produced during the hospital care activities, useful for future medical visits and surgical operations, amd for possible health policy-making procedures.

\subsection{Assessing social ecological costs: the emergy table}

The main inflows for the Salam Centre to operate in our reference year are expressed (Table 2) with both their original unit and their emergy unit, converted through either already published or original UEVs. Data sources, UEV references, and calculation processes are all reported as footnotes to Table 2.

Table 2. Emergy accounting assessment of the Salam Centre's activities on an annual basis

\begin{tabular}{|c|c|c|c|c|c|}
\hline Note & Item & Unit & $\begin{array}{l}\text { Amount } \\
\text { (unit/yr) }\end{array}$ & $\begin{array}{l}\text { UEV (*) } \\
\text { (sej/unit) }\end{array}$ & $\begin{array}{c}\text { Emergy } \\
(\mathrm{E}+14 \mathrm{sej} / \mathrm{yr})\end{array}$ \\
\hline \multicolumn{6}{|c|}{ Locally available renewable inputs $(R)$} \\
\hline 1 & Solar radiation & $\mathrm{J}$ & $2.27 \mathrm{E}+14$ & $1.00 \mathrm{E}+00$ & 23 \\
\hline \multirow[t]{2}{*}{2} & Geothermal heat flow & $\mathrm{J}$ & $1.73 \mathrm{E}+06$ & $4.90 \mathrm{E}+03$ & $<<1$ \\
\hline & & & \multicolumn{2}{|c|}{ Sum of the primary flows } & 23 \\
\hline 3 & Wind, kinetic energy & $\mathrm{J}$ & $8.05 \mathrm{E}+10$ & $7.90 \mathrm{E}+02$ & $<1$ \\
\hline 4 & Rain, geopotential & $\mathrm{J}$ & $8.09 \mathrm{E}+09$ & $1.28 \mathrm{E}+04$ & 1 \\
\hline \multirow[t]{3}{*}{5} & Water, from Nile-supplied local wells & $\mathrm{m}^{3}$ & $2.37 \mathrm{E}+04$ & $4.96 \mathrm{E}+11$ & 118 \\
\hline & & \multicolumn{3}{|c|}{ Largest of the secondary and tertiary flows } & 118 \\
\hline & & & \multicolumn{2}{|c|}{ Driving renewable input** } & 118 \\
\hline \multicolumn{5}{|c|}{ Locally available nonrenewable inputs (N) } & 0 \\
\hline \multicolumn{6}{|c|}{ Imported inputs $(F)$} \\
\hline
\end{tabular}




\begin{tabular}{|c|c|c|c|c|c|}
\hline 6 & Natural gas & $\mathrm{m}^{3}$ & $1.82 \mathrm{E}+04$ & $5.36 \mathrm{E}+12$ & 976 \\
\hline 7 & Diesel, for power and heating & $\mathrm{kg}$ & $4.01 \mathrm{E}+05$ & $6.12 \mathrm{E}+12$ & 24,541 \\
\hline 8 & Diesel, for vehicles & $\mathrm{kg}$ & $2.52 \mathrm{E}+04$ & $6.12 \mathrm{E}+12$ & 1,542 \\
\hline 9 & Electricity & $\mathrm{J}$ & $9.83 \mathrm{E}+12$ & $2.21 \mathrm{E}+05$ & 21,724 \\
\hline \multicolumn{6}{|c|}{ Goods and machinery*** } \\
\hline & (Bioclimatic building) & & & & \\
\hline 10 & Concrete, reinforced $18 \%$, groundwork & $\mathrm{kg}$ & $9.82 \mathrm{E}+04$ & $1.58 \mathrm{E}+12$ & 1,552 \\
\hline 11 & Steel, for ground floor framework & $\mathrm{kg}$ & $5.94 \mathrm{E}+03$ & $3.26 \mathrm{E}+12$ & 194 \\
\hline 12 & Clay bricks & $\mathrm{kg}$ & $7.22 \mathrm{E}+04$ & $1.83 \mathrm{E}+12$ & 1,321 \\
\hline 13 & Expanded polystyrene (as plastics) & $\mathrm{kg}$ & $7.87 \mathrm{E}+01$ & $6.48 \mathrm{E}+12$ & 5 \\
\hline 14 & Gypsum plasterboard (as gypsum) & $\mathrm{kg}$ & $1.13 \mathrm{E}+04$ & $7.89 \mathrm{E}+11$ & 89 \\
\hline 15 & Plaster & $\mathrm{kg}$ & $2.28 \mathrm{E}+03$ & $2.60 \mathrm{E}+12$ & 59 \\
\hline 16 & Sand, unspecified, for screed & $\mathrm{kg}$ & $1.00 \mathrm{E}+04$ & $1.56 \mathrm{E}+09$ & $<1$ \\
\hline 17 & Cement, for screed & $\mathrm{kg}$ & $2.19 \mathrm{E}+03$ & $1.64 \mathrm{E}+12$ & 36 \\
\hline 18 & Ceramic tiles & $\mathrm{kg}$ & $5.51 \mathrm{E}+03$ & $4.27 \mathrm{E}+12$ & 235 \\
\hline 19 & Paint & $\mathrm{kg}$ & $1.83 \mathrm{E}+03$ & $1.38 \mathrm{E}+13$ & 253 \\
\hline 20 & Rockwool & $\mathrm{kg}$ & $1.87 \mathrm{E}+03$ & $1.45 \mathrm{E}+12$ & 27 \\
\hline 21 & Steel plate & $\mathrm{kg}$ & $1.72 \mathrm{E}+03$ & $3.26 \mathrm{E}+12$ & 56 \\
\hline 22 & Door windows (2 m x $1 \mathrm{~m})$ & item & $5.75 \mathrm{E}-01$ & $2.27 \mathrm{E}+15$ & 13 \\
\hline 23 & Windows, double-glass $(0.7 \mathrm{~m} \times 0.7 \mathrm{~m})$ & item & $3.00 \mathrm{E}+00$ & $5.56 \mathrm{E}+14$ & 17 \\
\hline 24 & Saf leaves, dried, for screening panels & $\mathrm{kg}$ & $8.44 \mathrm{E}+01$ & $4.64 \mathrm{E}+08$ & $<<1$ \\
\hline 25 & $\begin{array}{l}\text { Wood, hard, mixed, for screen. panels } \\
\text { (Solar thermal plant) }\end{array}$ & $\mathrm{kg}$ & $3.39 \mathrm{E}+01$ & $9.38 \mathrm{E}+09$ & $<<1$ \\
\hline 26 & Solar thermal panels, ground-mounted & $\mathrm{m}^{2}$ & $4.95 \mathrm{E}+01$ & $4.85 \mathrm{E}+14$ & 240 \\
\hline 27 & Steel main pipes, for solar plant & $\mathrm{kg}$ & $1.13 \mathrm{E}+02$ & $3.26 \mathrm{E}+12$ & 4 \\
\hline 28 & Glass wool, insulation for main pipes & $\mathrm{kg}$ & $2.50 \mathrm{E}-01$ & $7.69 \mathrm{E}+12$ & $<1$ \\
\hline 29 & PVC tubes (as plastics) & $\mathrm{kg}$ & $5.02 \mathrm{E}+01$ & $6.48 \mathrm{E}+12$ & 3 \\
\hline 30 & Chillers (as air compressors) & item & $5.50 \mathrm{E}-01$ & $3.29 \mathrm{E}+15$ & 18 \\
\hline 31 & $\begin{array}{l}\text { Lithium Bromide } \\
\text { (Biomedical and technical equipment) }\end{array}$ & $\mathrm{kg}$ & $1.25 \mathrm{E}+00$ & $8.01 \mathrm{E}+12$ & $<1$ \\
\hline 32 & Electric / electronic appliances $(7.5 \mathrm{~kg})$ & item & $2.43 \mathrm{E}+01$ & $1.26 \mathrm{E}+14$ & 31 \\
\hline 33 & Electric / electronic appliances (30 kg) & item & $9.67 \mathrm{E}+00$ & $9.90 \mathrm{E}+14$ & 96 \\
\hline 34 & Electric / electronic appliances (75 kg) & item & $3.40 \mathrm{E}+00$ & $5.40 \mathrm{E}+14$ & 18 \\
\hline 35 & Electric / electronic appliances $(125 \mathrm{~kg})$ & item & $2.00 \mathrm{E}+00$ & $9.02 \mathrm{E}+14$ & 18 \\
\hline 36 & Surgery equipment, extra small (steel) & $\mathrm{kg}$ & $1.20 \mathrm{E}+00$ & $3.26 \mathrm{E}+12$ & $<1$ \\
\hline 37 & Bed and stretchers, as inpatient bed & item & $3.65 \mathrm{E}+00$ & $3.34 \mathrm{E}+14$ & 12 \\
\hline 38 & Monitors (as displays, liquid crystal) & item & $2.70 \mathrm{E}+00$ & $6.06 \mathrm{E}+14$ & 16 \\
\hline 39 & $\begin{array}{l}\text { Printer, laser, colour } \\
\text { (General furniture) }\end{array}$ & item & $3.50 \mathrm{E}-01$ & $1.93 \mathrm{E}+14$ & 1 \\
\hline 40 & Chairs, wood / steel mix & item & $6.93 \mathrm{E}+00$ & $5.85 \mathrm{E}+12$ & $<1$ \\
\hline 41 & Benches, wood & item & $1.13 \mathrm{E}+00$ & $1.33 \mathrm{E}+13$ & $<1$ \\
\hline 42 & Desks, wood & item & $1.13 \mathrm{E}+00$ & $1.33 \mathrm{E}+14$ & 2 \\
\hline 43 & Cabinets and lockers, wood & item & $3.90 \mathrm{E}+00$ & $2.97 \mathrm{E}+11$ & $<1$ \\
\hline 44 & Sanitary ceramics & $\mathrm{kg}$ & $3.90 \mathrm{E}+01$ & $3.71 \mathrm{E}+12$ & 1 \\
\hline 45 & Steel taps and fittings (as steel) & $\mathrm{kg}$ & $4.13 \mathrm{E}+00$ & $3.26 \mathrm{E}+12$ & $<1$ \\
\hline 46 & Kitchen equipment (ad Fridge) & item & $4.00 \mathrm{E}-01$ & $6.42 \mathrm{E}+14$ & 3 \\
\hline 47 & Bedframes, wood, non-medical & item & $2.10 \mathrm{E}+00$ & $3.46 \mathrm{E}+13$ & 1 \\
\hline 48 & $\begin{array}{l}\text { Matresses, polymer foam, non-medical } \\
\text { (Vehicle fleet) }\end{array}$ & item & $2.10 \mathrm{E}+00$ & $3.73 \mathrm{E}+13$ & 1 \\
\hline 49 & Cars & item & $5.50 \mathrm{E}-01$ & $9.48 \mathrm{E}+15$ & 52 \\
\hline 50 & Mini-vans & item & $1.00 \mathrm{E}-01$ & $1.82 \mathrm{E}+16$ & 18 \\
\hline 51 & $\begin{array}{l}\text { Pick-ups } \\
\text { (Consumables) }\end{array}$ & item & $1.00 \mathrm{E}-01$ & $1.57 \mathrm{E}+16$ & 16 \\
\hline
\end{tabular}




\begin{tabular}{|c|c|c|c|c|c|}
\hline 52 & Drugs, pharmaceuticals & $\mathrm{kg}$ & $1.53 \mathrm{E}+04$ & $5.76 \mathrm{E}+12$ & 881 \\
\hline 53 & Pharmaceutical containers, glass & $\mathrm{kg}$ & $2.12 \mathrm{E}+03$ & $1.71 \mathrm{E}+12$ & 36 \\
\hline 54 & Pharmaceutical containers, plastics & $\mathrm{kg}$ & $1.22 \mathrm{E}+04$ & $6.48 \mathrm{E}+12$ & 791 \\
\hline 55 & Pharmaceutical containers, aluminum & $\mathrm{kg}$ & $2.48 \mathrm{E}+03$ & $9.90 \mathrm{E}+12$ & 246 \\
\hline 56 & Vegetables \& fruits, Sudanese local & $\mathrm{kg}$ & $9.50 \mathrm{E}+03$ & $2.83 \mathrm{E}+11$ & 27 \\
\hline 57 & Meat, Sudanese local & $\mathrm{kg}$ & $3.05 \mathrm{E}+03$ & $1.94 \mathrm{E}+13$ & 591 \\
\hline 58 & Fish, Sudanese local & $\mathrm{kg}$ & $1.52 \mathrm{E}+03$ & $6.21 \mathrm{E}+13$ & 946 \\
\hline 59 & Dairy products (as milk) & $\mathrm{kg}$ & $2.54 \mathrm{E}+03$ & $2.66 \mathrm{E}+13$ & 675 \\
\hline 60 & Bread, cereals, eggs (as average food) & $\mathrm{kg}$ & $7.51 \mathrm{E}+04$ & $8.84 \mathrm{E}+12$ & 664 \\
\hline \multirow[t]{2}{*}{61} & Fabric for uniforms (textiles) & $\mathrm{kg}$ & $3.65 \mathrm{E}+02$ & $1.80 \mathrm{E}+13$ & 66 \\
\hline & (Transportation of goods \& machinery) & & & & \\
\hline 62 & Transportation, items 10-25 (as diesel) & $\mathrm{kg}$ & $2.96 \mathrm{E}+03$ & $6.12 \mathrm{E}+12$ & 181 \\
\hline 63 & Transportation, items $26-31$ (as diesel) & $\mathrm{kg}$ & $3.08 \mathrm{E}+01$ & $6.12 \mathrm{E}+12$ & 2 \\
\hline 64 & Transportation, items 32-39 (as diesel) & $\mathrm{kg}$ & $2.97 \mathrm{E}+01$ & $6.12 \mathrm{E}+12$ & 2 \\
\hline 65 & Transportation, items $40-48$ (as diesel) & $\mathrm{kg}$ & $1.06 \mathrm{E}+01$ & $6.12 \mathrm{E}+12$ & 1 \\
\hline 66 & Transportation, items $49-51$ (as diesel) & $\mathrm{kg}$ & $1.41 \mathrm{E}-01$ & $6.12 \mathrm{E}+12$ & $<1$ \\
\hline 67 & Transportation, items 52-61 (as diesel) & $\mathrm{kg}$ & $3.29 \mathrm{E}+03$ & $6.12 \mathrm{E}+12$ & 202 \\
\hline \multicolumn{6}{|c|}{ Labour \& Services $(L \& S)$} \\
\hline \multirow[t]{3}{*}{68} & Labour, as full-time equivalent workers & & & & \\
\hline & - local staff (Sudan-based) & unit & 700 & $8.90 \mathrm{E}+15$ & 62,300 \\
\hline & - international staff (from Italy) & unit & 20 & $7.96 \mathrm{E}+16$ & 15,920 \\
\hline \multirow[t]{10}{*}{69} & Services & & & & \\
\hline & - items 6-9, fuels and electricity & SDG & $2.47 \mathrm{E}+06$ & $1.01 \mathrm{E}+12$ & 24,975 \\
\hline & - items $10-31$, bioclimatic buildings & SDG & $1.30 \mathrm{E}+06$ & $1.01 \mathrm{E}+12$ & 13,130 \\
\hline & - items $32-39$, biomedical \& technical & $€$ & $3.24 \mathrm{E}+05$ & $3.08 \mathrm{E}+12$ & 9,973 \\
\hline & - items $40-51$, furniture \& vehicles & SDG & $1.19 \mathrm{E}+05$ & $1.01 \mathrm{E}+12$ & 1,207 \\
\hline & - items 52-55, pharmaceuticals & $€$ & $1.94 \mathrm{E}+06$ & $3.08 \mathrm{E}+12$ & 59,771 \\
\hline & - items 56-61, other consumables & SDG & $1.10 \mathrm{E}+06$ & $1.01 \mathrm{E}+12$ & 11,129 \\
\hline & - shipping (courier, container, cargo) & $€$ & $1.73 \mathrm{E}+05$ & $3.08 \mathrm{E}+12$ & 5,325 \\
\hline & - other local services & SDG & $2.20 \mathrm{E}+06$ & $1.01 \mathrm{E}+12$ & 22,210 \\
\hline & - other international services & $€$ & $4.37 \mathrm{E}+05$ & $3.08 \mathrm{E}+12$ & 13,451 \\
\hline \multicolumn{6}{|c|}{ Main output } \\
\hline \multicolumn{2}{|c|}{ Total Emergy input (U) } & & & & $5.86 \mathrm{E}+18$ \\
\hline \multicolumn{2}{|c|}{ Total Emergy input with labour \& services (ULS) } & & & & $2.98 \mathrm{E}+19$ \\
\hline Annu & patient-days & p-day & 16,097 & & \\
\hline
\end{tabular}

*Calculated or converted from other works according to the $\mathbf{G E B}_{2016}$ of $1.2 \mathrm{E}+\mathbf{2 5} \mathrm{seJ}$ [75]

**Based on [71], we only use the largest between the sum of the tripartite sources (solar radiation, heat flow, and tides, where applicable) and the largest of secondary and tertiary sources.

***Our engineering calculations based on data from NGO Emergency and hospital administration.

Footnotes: Hospital area: $4.0 \mathrm{E}+04 \mathrm{~m}^{2}$ (i.e. 4 ha). 1. Daily solar insolation in Khartoum: $6.18 \mathrm{kWh} / \mathrm{m}^{2} /$ day (data from hospital administration, double checked with Boukelia \& Mecibah [81]); albedo of built / green mix: 0.3 (our assumption based on Taha [82]). 2. Local heat flow: $55 \mathrm{~mW} / \mathrm{m}^{2}$ (based on Hamza \& Vieira [83]). 3. Average annual local surface wind speed: $4.7 \mathrm{~m} / \mathrm{s}$ (based on offical records from local HSSS weather station at Khartoum International Airport); surface wind / geostrophic wind ratio: 0.58 (Reiter [84], as cited in [85]); drag coefficient: 1.00E-03 [86]; average density of air in the area: $1.2 \mathrm{~kg} / \mathrm{m}^{3}$ (our assumption based on local elevation). 4. Elevation: $382 \mathrm{~m}$ (Khartoum official records); annual rainfall: $135 \mathrm{~mm}$ [87]; runoff on the Salam's built / green mix environment: 0.4 (our estimation based on previous literature). 5. Data from hospital administration, doublechecked. 6-9. Data from hospital administration. 10-11. Lifetime: $80 \mathrm{yrs.} \mathrm{12-18.} \mathrm{Lifetime:} 40 \mathrm{yrs}$. 19. Lifetime: 10 yrs. 20-23. Lifetime: 40 yrs. 24-31. Lifetime: 20 yrs. 32-36. Lifetime: 15 yrs. 37-39. Lifetime: 20 yrs. 4045. Lifetime: 30 yrs. 46-51. Lifetime: 20 yrs. 52-55. Our detailed calculations based on NGO and hospital records. 62-67. Adjusted to items' lifetimes; including air, maritime, and on-road transport; due to their significant order of magnitude, fuels only are considered. 68-69. Our economic calculations based on hospital records and (where applicable) lifetimes; maintenance is included among the other services (general maintenance as local, biomedical maintenance as international). 
UEV references: 1. By definition. 2-6. After De Vilbiss \& Brown [88]. 7- 8. Brown et al. [89]. 9. National Environmental Accounting Database (NEAD), Sudan, 2014 (after [90] and [91]). 10. Our calculation based on Brown \& Buranakarn [52] and Pulselli et al. [53]. 11-14. Brown \& Buranakarn [52]. 15. Meillaud et al. [48]. 16. After De Vilbiss \& Brown [88]. 17-18. Brown \& Buranakarn [52]. 19. This work ${ }^{\#}$ 20. Björklund et al. [92]. 21. Brown \& Buranakarn [52]. 22-23. This work ${ }^{\#}$. 24. Our calculation based on Odum \& Collins [93]. 25. After De Vilbiss \& Brown [88]. 26. This work ${ }^{\#}$. 27. Brown \& Buranakarn [52]. 28. This work ${ }^{\#}$. 29. Brown \& Buranakarn [52]. 30-35. This work ${ }^{\#}$ 36. Brown \& Buranakarn [52]. 37-44. This work ${ }^{\#}$ 45. Brown \& Buranakarn [52]. 46-48. This work ${ }^{\#}$. 49. Lou et al. [94]. 50-51. Our calculation based on Lou et al. [94]. 52. This work ${ }^{\#}$. 53-55. Brown \& Buranakarn [52]. 56-58. NEAD, Sudan, 2014(after [90] and [91]). 62-67. Brown et al. [89]. 68-69. NEAD, Italy and Sudan, 2014 (after [90] and [91]); based on 2010-2015 trends, 1.3 EUR/USD and 5.0 USD/SDG conversion rates are adopted for UEV adjustments; SDG = Sudanese pound, USD = United States dollar.

\#LCA-based emergy calculations for item production (including energy and material generation, concentration, extraction, transportation, and processing).

\subsection{Hospital UEVs and emergy indicators}

Some UEVs are specifically calculated for our evaluation (Table 2), since several items typical of hospitals and buildings were not present or reliable in the scientific literature of such underexplored fields. Nonetheless, some UEVs are proposed and calculated at the end of our evaluation (Table 3), specifically designed for health systems, and associated with the hospital's main co-products. Following the metrics of patient-day, common in healthcare management, we first introduce a UEV called "Emergy per patient-day", related to the number of inpatients hosted at the hospital, and to their days of bed occupancy (similarly to the concept of emergy per passenger-kilometre as introduced for transport systems by Federici et al. [44]). Likewise, two more new unit emergy values express the emergy per cardiac surgical operation and the emergy per cardiological visit. The former also includes a small number of cath lab procedures (as per Table 1), the latter encompasses both inpatient and outpatient visits. An outpatient visit is usually functional to hospedalisation and operation, if required, or acts as a post-operative follow-up. In hospitals offering other fields of specialisation, these UEVs could be generalised as "Emergy per surgical operation" and "Emergy per medical (or specialised) visit", or - especially in Emergency Rooms - "per triage".

Table 3 - New unit emergy values for the Salam Centre

\begin{tabular}{|l|c|c|c|}
\hline \multicolumn{1}{|c|}{ UEV } & $\begin{array}{c}\text { Value } \\
\text { without L\&S }\end{array}$ & $\begin{array}{c}\text { Value } \\
\text { with L\&S }\end{array}$ & unit \\
\hline Emergy per patient-day & $3.64 \mathrm{E}+14$ & $1.85 \mathrm{E}+15$ & sej/p-day \\
\hline Emergy per cardiac surgical operation & $1.06 \mathrm{E}+16$ & $5.40 \mathrm{E}+16$ & sej/operation \\
\hline Emergy per cardiological visit & $8.86 \mathrm{E}+14$ & $4.50 \mathrm{E}+15$ & sej/visit \\
\hline
\end{tabular}

As introduced in section 2.2, some emergy indicators from existing literature are calculated (Table 4). All indicators are expressed both with and without the emergy associated with labour and services. If several of them are usually present in most emergy evaluations, a remark ought to be dedicated to the Renewable Support Area $\left(\mathrm{SA}_{(\mathrm{r})}\right)$. As explained by Brown and Ulgiati (2001) [95], this suggests the carrying capacity (as Earth surface necessary to support the hospital activities). The calculation of the $\mathrm{SA}_{(\mathrm{r})}$ resorts to the local renewable empower density $\left(\operatorname{Empd}_{(\mathrm{r})}\right)$, that is the annual renewable flow $(\mathrm{R})$ divided by the total area of the lot where the Salam Centre lies. In Brown and Ulgiati's own words [95], $\mathrm{SA}_{(\mathrm{r})}$ is "the necessary area of the surrounding region that would be required if the economic activity were using solely renewable emergy inputs". Through a parallel with the way more popular ecological fooprint [96], we might define the Renewable Support Area as an Emergy-based land fooprint.

Table 4 - Emergy indicators for the Salam Centre

\begin{tabular}{|c|c|c|}
\hline Category & Equation & Value (sej/yr) \\
\hline $\mathrm{R}$ & & $1.18 \mathrm{E}+16$ \\
\hline $\mathrm{N}$ & & 0 \\
\hline $\mathrm{F}$ & & $5.85 \mathrm{E}+18$ \\
\hline
\end{tabular}




\begin{tabular}{|c|c|c|}
\hline L\&S & & $2.39 \mathrm{E}+19$ \\
\hline $\mathrm{U}$ & $\mathrm{R}+\mathrm{N}+\mathrm{F}$ & $5.86 \mathrm{E}+18$ \\
\hline ULS & $\mathrm{U}+\mathrm{L} \& \mathrm{~S}$ & $2.98 \mathrm{E}+19$ \\
\hline Indicator & Equation & Value \\
\hline EYR & $\mathrm{U} / \mathrm{F}$ & 1.002 \\
\hline $\mathrm{EYR}_{\mathrm{L} \& \mathrm{~S}}$ & ULS/(F+L\&S) & 1.000 \\
\hline ELR & $(\mathrm{F}+\mathrm{N}) / \mathrm{R}$ & 496 \\
\hline$E_{L L R} \& S$ & $(\mathrm{~F}+\mathrm{N}+\mathrm{L} \& \mathrm{~S}) / \mathrm{R}$ & 2,524 \\
\hline$\% \mathrm{R}$ & $\mathrm{R} / \mathrm{U}$ & $0.20 \%$ \\
\hline$\% \mathrm{R}_{\mathrm{L} \& \mathrm{~S}}$ & R/ULS & $0.04 \%$ \\
\hline ESI & EYR/ELR & 0.002 \\
\hline $\mathrm{ESI}_{\mathrm{L} \& \mathrm{~S}}$ & $\mathrm{EYR}_{\mathrm{L} \& \mathrm{~S}} / \mathrm{ELR}_{\mathrm{L \& S}}$ & 0.000 \\
\hline $\mathrm{AEI}_{\text {outdoor }}$ & $\mathrm{U} /$ (outdoor area) & $1.5 \mathrm{E}+14 \mathrm{sej} / \mathrm{m}^{2}$ \\
\hline $\mathrm{AEI}_{\text {outdoor L\&S }}$ & ULS/(outdoor area) & $7.5 \mathrm{E}+14 \mathrm{sej} / \mathrm{m}^{2}$ \\
\hline $\mathrm{AEI}_{\text {indoor }}$ & U/(indoor area) & $4.9 \mathrm{E}+14 \mathrm{sej} / \mathrm{m}^{2}$ \\
\hline $\mathrm{AEI}_{\text {indoor } \mathrm{L \& S}}$ & ULS/(indoor area) & $2.5 \mathrm{E}+15 \mathrm{sej} / \mathrm{m}^{2}$ \\
\hline $\mathrm{SA}_{(\mathrm{r})}$ & $(\mathrm{F}+\mathrm{N}) / \mathrm{Empd}_{(\mathrm{r})}$ & $1,983 \mathrm{ha}$ \\
\hline $\mathrm{SA}_{(\mathrm{r}) \mathrm{L} \& \mathrm{~S}}$ & $(\mathrm{~F}+\mathrm{N}+\mathrm{L} \& \mathrm{~S}) / \mathrm{Empd}_{(\mathrm{r})}$ & 10,098 ha \\
\hline
\end{tabular}

\section{Discussion}

Working side by side with many members of the Salam Centre and the Humanitarian Office of NGO Emergency, we have obtained a very detailed inventory, partly expressed in Table 2 . Such table, together with its footnotes, provides insights for a thorough understanding of the quality and original quantities of the manifold inputs required to run a top-level hospital like the one at issue. However, it is the associated emergy units - core of the present study - to offer interesting results. As a top-level specialised hospital with advanced Global Northern healthcare standards, our system is alien to the native ecosystems of a shore of the Nile river. This has implications in both the emergy evaluation (Table 2) and its indicators (Table 4).

In spite of an accurate architectural and engineering design and of a relatively short lifetime, imposed by adverse climate conditions, the annual material inputs for the construction of the bioclimatic structures and energy systems require relatively low resources (i.e., one order of magnitude smaller than the driving energy and material inputs). This can be read as a success, and positively matches with the Salam Centre's benefits of low-tech design in energy saving, which we previously found out [16]. Savings apart, the major inputs are rather represented by fuels and electricity. Diesel is required to ensure the demanding indoor climate conditions, and electricity to supply the complex biomedical equipment, including ventilators, often active 24/7. Although typical of a hospital, such machineries consume large amounts of energy but are relatively "light" in terms of annual allocation of emergy for their production and delivery. Instead, after energy resources and building inputs, the third largest cluster of inputs is represented by consumables. Here, besides patients' food, another typical healthcare input is present, i.e., pharmaceuticals.

The situation is different when services are included. In this respect, pharmaceuticals are maybe the most representative item. The emergy associated with their services (based on their price) is nearly 30 times larger than the geobiophysical emergy required for the concentration, extraction, and progressive processing of their ingredients. While the chemical accounting can be considered as averagely easy, and their ingredients usually not rare, know-how and decennial experiments might play a role, together with other features of an exceptional sector. For instance, price-related issues involving market dynamics such as oligopoly and profit, which we propose as able to alterate the significance of the associated emergy values, and which we will further specifically address in specially dedicated works in progress.

Similarly, also labour has a prominent role in the emergy accounting. Again, this can be ascribed, on the one hand, to the number of workers required to run such a complex system, where medical professionals are only a part of the total involved labourforce; on the other hand, for the specific characteristics of the Salam Centre, to the reliance upon international medical and sanitary staff, coming from abroad and averagely living Global Northern lives. We would like to stress that this is calculated through the emergy associated with equivalent full-time workers, i.e., to the emergy per capita of the societies and economies from where the 
workers come, hence a differentiation between Sudanese residents and international (Italian) temporary expats. A similar distinction would be theoretically still present if we calculated labour emergy through their wages, but this would distort our analysis since we are in the presence of interns, workers in traineeship, and sometimes voluntary workers, so a partial or symbolic salary would alter our results. We start to propose that this featuring dilemma related to nonprofit systems might be the basis for further discourses on labour, upon which we are also working, and which we will resume in future works.

Concerning local renewables, if the solar thermal plant yields positive outcomes, the driving source is surprisingly represented by the freshwater supplied by the nearby river, and available for pumping and safe filtration in the water-bearing strata under the lot of the hospital. It might be worth noticing that our tailored UEVs for hospitals are calculated as associated with co-products. In fact, specialised visits, operations, and stays in the hospital wards are all functional and interconnected one to another. Similarly, the knowledge and information that we include in the diagram, if quantified, would still be a co-product, since they would emerge from the medical practice. Since such UEVs that we first propose and introduce are pioneers in our emergy field, no comparison is possible for the moment. Nevertheless, they represent a benchmark for possible future studies in the field of health systems, requiring more and more attention in this turbulent times.

Considering labour and services altogether, we can realise that they account for nearly the $80 \%$ of the total annual emergy requirements of the Salam Centre. This is the highest ratio ever found in an emergy assessment, yet some explanations exist. We are indeed in the presence of a complex system like a specialised hospital operating far away from where its key factors are produced or trained. Before our study, few other high skills- and patent-intensive systems have exhibited ratios higher than $50 \%$. This is the case of those involving agricultural processes through transgenic technologies [97][98]. The level of complexity of the Salam Centre is evidently higher, and so is the alien nature of a specialised hospital with Global Northern in a context not at all rich in the resources that are required to fuel its featuring processes. Moreover, if a hospital partly operated similarly to an industry, its inputs are all from secondary and tertiary sectors, i.e., skilled labour and top-quality highly sophisticated final products, which do not deliver a product, but a service: healthcare. We therefore propose this condition as a "double-level tertiary" activity, with very few similar processes that at present we cannot find as a case study of any other previous emergy accounting evaluation.

Based on such a peculiarity and following some warnings about some possible uncertainties affecting the emergy accounting [99], a sensitivity analysis [100] is also performed. Well then, artificial alterations of up to $20 \%$ onto the major inputs would only yield minor changes (i.e., usually one or more orders of magnitude smaller) in the total emergy driving the process as well as in the various indicators. We argue that this is mostly due, on the one hand, to the variety of inputs with similar emergy value, and on the other hand to the impressive number of items that we analyse thanks to an extremely detailed inventory. We therefore maintain that the quality and quantity of our data ensure a fair protection from uncertainty.

Finally, important considerations can be drawn from a careful interpretation of the emergy indicators. The emergy yield ratio (EYR), very close to its minimum value (1, i.e., total emergy coinciding with imported emergy) confirms that the Salam Centre is mostly a "consumer" system, scarcely able to make local resources available, and for which the outer societies and economies operate (or, at least, should operate). The latter seems to us as a reasonable insight, to be recalled in our conclusions. The environmental loading ratio (ELR) records a relevant pressure, disturbance of the system at issue onto the native environment: as mentioned above, the shores of a river in a quasi-desertic area are not the most suitable place for a highly specialised hospital, yet a need for free-of-charge quality specialised healthcare is present in an area of 300,000 millions, and the value of the ELR is a cleary consequence of such "daring the impossible". This also suggests that such a challenge is quite framed in complex international, North-South relations, not independent of the local and international economic and socio-ecological conditions. Like the EYR, also the emergy sustainability index (ESI) registers a higly-developed, final-user-oriented system. Besides being to some extent an intrinsic feature of a hospital, this is even more true in a structure with Global Northern standards, mostly run by a foreign NGO. The renewable emergy percentage (\%Ren) confirms an overall dependence upon imported inputs, yet its location on the shores of a major river provides the Salam Centre with non-obvious values compared to the other indicators (i.e., up to $0.2 \%$ ). So does the Renewable Support Area $\left(\mathrm{SA}_{(\mathrm{r})}\right)$. In reason of its own nature, it is unfrequent that a Global Northern specialised hospital, depending on sophisticated technology, is sustainable and fully relying on its local resources ${ }^{11}$. Nonetheless, its strategic location close to a major river

\footnotetext{
${ }^{11}$ Please note that such a heavy dependence upon imported labour and goods regards specialised hospitals, typical of conventional medicine; addressing general symptoms by millennial natural cures such as in Chinese or Latin American traditional medicine are out of the scopes of this paper, and out of the competences of non-medical scholars like us.
} 
and rich in solar radiation seems to partly make up for its starting conditions. As suggested for civil structures [41], the hospital administration can use an assessment like this to improve its performances over time. This is something that can be replicated at the Salam Centre, at other hospitals, and at other complex public or private, profit or nonprofit organisations.

Starting from the anyway huge emergy requirements associated with a complex system such as a hospital, some considerations ought to be made. Of course our approach allows to identify possible critical points in the system so as to suggest strategies - where applicable - to reduce resource consumption in the industry-like processes [101] of the hospital. However, some positive hints already arrive from the one last indicator. In fact, it might be worth underlying that the areal empower intensity (AEI) of the Salam Centre still results one or two orders of magnitude smaller than the single- or multi-unit residential buildings investigated [53][49][50] in Europe and in North America. With one tenth or even one hundredth of resources compared to those required to just tickle spoilt dwellers of maybe fancy "sustainable" apartments, lives are saved at the Salam Centre. This appears as an extremely important datum, since it might bring us to address and question the general societal attitude of the wealthier parts of the world towards anyway scarcer and scarcer global resources, and hence towards the implicit or explicit priorities of our societies. Just to use some UEVs already used or at least cited in the present paper, $18 \mathrm{~kg}$ of meat require as much emergy as one day as a patient at the Salam Centre (and we all know how impacting and resource-demanding meat production is per se). The emergy required for one sport utility vehicle (SUV) would allow for no less ${ }^{12}$ than one and a half life-saving open-heart operations at the Salam Centre. And one SUV transported on a hypothetical ${ }^{13}$ high-speed $\operatorname{train}^{14}$ from Turin, Italy, and Lyon, France would take away from ecological systems and human societies the same emergy amounts that would allow for a cardiological visit. This is not to blame on single consumers, but rather to frame the issue of resource scarcity in a wider discourse on societal priorities, including wealth distribution (as systemically drafted in [79]), so as to possibly address resource distribution and health systems in a comprehensive and coherent way.

In fact, it ought not to be forgotten that North-South medical cooperation is still framed in unbalanced postcolonial relations and subject to economic, geo-political, and social oscillations, which in parallel should be addressed too. It is in this framework that our systemic diagramming of health systems highlights the criticalities that are just now re-emerging with the Covid-19 pandemic. As noted [2] soon after the outbreak of such emergency, closing borders and self-concerned wealthy nations unmask the asymmetrical power structures dominating both Global Northern and Southern countries, including Africa. This also reminds us of how unsustainable and hardly resilient the whole sector can be at present (with a special regard to poor contexts in wealthy countries and to disadvantaged countries in general) if a human right and universal value [104] like health is commodified or at least not prioritised, and the issues are not addressed at a systemic level. A systemsbased perspective also suggests that the number of patients plays a role in the delivery of health services. Thus, health prevention can reduce the need for cures, and make the still required ones more effective. In this sense, the recent Covid-19 crisis also teaches us that its zoonotic origin [105] is linked to the ecosystemic alterations structurally caused by a predatory and exploitative paradigm. Following a recent stream [2][106][107], our work aims at contributing to global meditation in such critical period to find adequate solutions to increase the sustainability and resilience of health systems, i.e., reinforcing the global preparedness to "the next big one" instead of coming back to the same, problematic business as usual.

From a qualitative viewpoint, as per the systems diagram (Fig. 3), it emerges that the dependence upon know-how and products from the outer economy is a critical point of the Salam Centre. This is even more true if required goods and workers come from far away. The development of local specialised manufacturing for biomedicals and pharmaceuticals is something hard to propose and control in delicate ecological and socioeconomic global contexts. The decrease in the dependence on foreign labour force, instead, seems as a promising strategy. In this sense, the circle of interns, helping our in medical operations while being trained in excellence specialised medicine, stands out as a reinforcing mechanism for the whole system, towards its resilience to external changes. In fact, the willingness of foreign specialised staff to leave for Sudan and work there for a while, just like the possibility and desire to donate labour, money, and services, all depend upon social, ecological, economic, and geo-political factors. (The ongoing pandemic and related re-emerging structural economic crisis in the Global North can be serve as examples; wars and other extreme events might play a role too). For a hospital run by a humanitarian NGO, the image of the charity organisation becomes a

\footnotetext{
${ }^{12}$ Lou et al. [94] do not account for some inputs in their UEV of a vehicle (as adapted in Table 2, item 51).

${ }^{13}$ See [102] and [103].

${ }^{14}$ Transportation UEVs by Federici et al. [45].
} 
leverage point, as it can activate or stop the crucial inputs to the system: medical success, hygiene, integrity, and overall reputation are all important aspects to keep in mind while managing such a complex structure. Nevertheless, the image by itself is not able to ensure a full control over the system, since the complex socioeconomic and geo-political features of a closely interconnected world are involved: depending upon predatory and often belligerent mechanisms, as per the types of exploitation of humans and resources described for instance in [79]. Concerning the resources, the management of the valuable local renewables can be improved, and the quali-quantitative environmental accounting method we use can be of great help in this. As also recently outlined [61], systems thinking can play a pivotal role to support the strengthening of the sustainability and resilience of complex systems, especially while facing an uncertain, fast changing century, not necessarily ensuring the same conditions upon which we now base, and thus, maybe, still to be re-invented. H.T. and Elizabeth Odum [108] talk about preparing information packages to save some key aspects of civilisation after possible global collapses, or to at least mitigate a collapse. With the provision of health for everyone being presumably a cornerstone independently of the social and economic main values of a given civilisation, the emergy-supported systems thinking application to health systems can be seen as much important as urgent in turbulent times like this.

\section{Conclusion}

In this paper, a systems-thinking- and LCA- based emergy assessment is applied to health systems. In particular, to a top-level specialised hospital in Sudan, designed in a brand-new bioclimatic building, and run by a humanitarian NGO from Italy. This is an absolute novelty for both hospitals and bioclimatic buildings. Our study suggests that:

- For their representing a complete novelty in both health systems and bioclimatic buildings, our emergy results, UEVs, and indicators are benchmarks for future studies. We offer a first step toward systemic studies on how to set up sustainable health services, needed at all levels; if crucial weakness may follow resource misuses, independently of their amount and quality, the comprehensive socio-ecological point of view allowed by systems thinking and emergy accounting can be a valid starting point to support health services.

- As an end-user service by definition, a hospital is a highly demanding system, for which imports from the outer economies and societies are crucial, being local inputs clearly not enough. Its indicators confirm that a health system cannot be created and maintained by itself, but the outer society is rather called to operate and leave resources for it to be granted. In other words, if health is a societal priority, then social and economic systems ought to be re-adjusted so as to promote it and, in a context of scarcity, to leave adequate resources (be them socio-ecological and/or financial) for healthcare systems and facilities. In particular, North-South medical cooperation is still framed in unbalanced postcolonial relations and subject to economic, geo-political, and social oscillations, which ought to be addressed too.

- At the Salam Centre, and we would dare to say in a nonprofit hospital, the image of the facility as well as of the managing organisation is a possibly strong leverage point.

- The evaluation of our hospital yields the highest ratio of labour and services ever found in emergy accounting; this is related to both a specialised hospital and a cooperation project. Actually, specialised healthcare can be seen as a "double-level tertiary activity", for it requires high-quality labour and final products to be used in industry-like processes delivering a service.

- The bioclimatic building suggests to actually have socio-ecological sustainability features, and the emergy requirements for its construction are limited; further developments on both this kind of building design, supported by a sound assessment tool like the one we use, can help address energy poverty and the demand for safe housing, in Africa and elsewhere. Improvements in the socio-ecological efficiency of a hospital are anyway possible; a systems- and LCA-based emergy evaluation here shows its potential to support them.

- At the Salam Centre, the performances in terms of emergy per area unit (areal empower density) are stunnigly positive if compared to other previously investigated civil works, namely, residential units; with much less, while delivering top-quality healthcare instead of pure housing is remarkable. Similarly, fruitful application can come for the design, assessment, and management of other complex systems (public or private, profit or 
nonprofit) in a complex, fast changing world: the lower the dependence upon scarce or uncertain inputs, the higher the system's resilience.

- The importance and the complexity of our study appears as particularly high in the light of the ongoing pandemic, with the entire world called to ensure a human right like health, again, through resilient societal and health systems.

- While it cannot be denied that the outputs of a cardiac surgical hospital require significant amounts of social ecological resources (here, in emergy terms) in global conditions of scarcity, this can be seen as a definitive reason to finally revise the priorities of the societies where we live. Granted that, from a systemic perspective, health prevention is likely to be more effective than cures and that the ecosystemic alterations structurally caused by a predatory and exploitative paradigm do play a role, when the resources required by medical services are compared to often superflous positional goods and services, and when inequalities and uncertainty arise from those predatory and exploitative global dynamics, then discourses on the ecological sustainability and social fairness/equity of the dominant economic system and societal values are implicitly involved, and a path to walk suggested.

\begin{abstract}
Acknowledgements
Portions of this study were conducted when Dr. Silvio Cristiano was affiliated with the Department of Design and Planning in Complex Environments at Università Iuav di Venezia, Venice, Italy. The Authors gratefully thank: Mr. Emanuele Nannini, Ms. Cecilia Strada, Dr. Gino Strada, Ms. Rossella Miccio, Mr. Roberto Crestan, Mr. Lorenzo Siracusano, Mr. Carlo Maisano, Ms. Giuseppina Buffa, Mr. Enrico Sponziello, and Ms. Francesca Basile (all from the various divisions and hospitals of humanitarian NGO Emergengy), photographer Mr. Marcello Bonfanti, and architect Mr. Raul Pantaleo (TAMassociati).
\end{abstract}

\title{
Author contributions
}

Most of the manuscript was contributed to by S.C., including literature search, figures, conceptualisation, data curation, and writing. As an expert in emergy accounting, S.U. checked that related method and results were solid, after transfering to him his expertise throughout the years. As an expert in systems thinking, F.G. coauthored with S.C. the parts concerning the description of such approach as well as its global health implications, and supervised the whole research process. All authors worked together on the systemic diagram for the Salam Centre, on the abstract, on the description of the indicators, and on the review and editing parts.

\section{Declaration of interests}

The authors declare that they have no known competing financial interests or personal relationships that could have appeared to influence the work reported in this paper.

\section{List of references}

[1] United Nations. Transforming our world: the 2030 Agenda for Sustainable Development; 2003. https://sustainabledevelopment.un.org/post2015/transformingourworld [accessed 23 April 2020]

[2] Editorial. Decolonising COVID-19. Lancet Glob Health 2020; 8(5): 612.

[3] World Economic Forum. Global Risk Report 2020; 2019. https://www.weforum.org/reports/the-globalrisks-report-2020 [accessed 2 April 2020]

[4] Nuclear Threat Initiative. Global Health Security Index: Inaugural Global Health Security Index Finds No Country Is Prepared for Epidemics or Pandemics. Press Release, 24 October 2019; 2019. https://www.nti.org/newsroom/news/inaugural-global-health-security-index-finds-no-countryprepared-epidemics-or-pandemics/ [accessed 28 April 2020]

[5] Phillips CA, Caldas A, Cleetus R, Dahl KA, Declet-Barreto J, Licker R, Delta Merner L, Ortiz-Partida JP, Phelan AL, Spanger-Siegfried E, Talati S, Trisos CH, Carlson CJ. Compound climate risks in the COVID-19 pandemic. Nat Clim Chang 2020. https://doi.org/10.1038/s41558-020-0804-2

[6] Redding DW, Atkinson PM, Cunningham AA, Iacono GL, Moses LM, Wood JL, Jones KE. Impacts of environmental and socio-economic factors on emergence and epidemic potential of Ebola in Africa. Nat commun 2019; 10(1): 1-11.

[7] van Staden C. COVID-19 and the crisis of national development. Nat Hum Behav 2020; 4, 443-4. https://doi.org/10.1038/s41562-020-0852-7 
[8] Liu X, Liu G, Yang Z, Chen B, Ulgiati S. Comparing national environmental and economic performances through emergy sustainability indicators: Moving environmental ethics beyond anthropocentrism toward ecocentrism. Renew Sust Energ Rev 2016; 58: 1532-42.

[9] Haberl H, Wiedenhofer D, Pauliuk S, Krausmann F, Müller DB, Fischer-Kowalski M. Contributions of sociometabolic research to sustainability science. Nat Sustain 2019; 2(3): 173-84.

[10] International Energy Agency. World Energy Outlook 2018. Paris: IEA Publications; 2018.

[11] Day R, Walker G, Simcock N. Conceptualising energy use and energy poverty using a capabilities framework. Energy Policy 2016; 93: 255-64.

[12] Monyei CG, Adewumi AO, Obolo MO, Sajou B. Nigeria's energy poverty: Insights and implications for smart policies and framework towards a smart Nigeria electricity network. Renew Sust Energ Rev 2018; 81: 1582-1601.

[13] Castán Broto V, Kirshner J. Energy access is needed to maintain health during pandemics. Nat Energy 2020. https://doi.org/10.1038/s41560-020-0625-6

[14] Pantaleo R, Strada G. Centro pediatrico di Emergency in Darfur. Domus 2011; 949.

[15] Sridharan V, Broad O, Shivakumar A, Howells M, Boehlert B, Groves DG, Rogner HH, Taliotis C, Neumann JE, Strzepek KM, Lempert R, Joyce B, Huber-Lee A, Cervigni R. Resilience of the Eastern African electricity sector to climate driven changes in hydropower generation. Nat commun 2019; 10(1): $1-9$.

[16] Cristiano S, Gonella F. Learning from hybrid innovative-vernacular solutions in building design. Systemic evaluation through emergy synthesis of technologies for energy saving in Sudan. J Environ Account Manag 2019; 7(2): 209-23.

[17] Pantaleo R. Attenti all'uomo bianco. Emergency in Sudan: diario di cantiere. Milano: Elèuthera; 2007.

[18] Jones DL, Hudson J. Architecture and the environment: bioclimatic building design. London: Laurence King; 1998.

[19] Olgyay V. Design with climate: Bioclimatic approach to architectural regionalism-new and expanded edition. Princeton: Princeton University Press; 2015.

[20] Beccali M, Strazzeri V, Germanà ML, Melluso V, Galatioto A. Vernacular and bioclimatic architecture and indoor thermal comfort implications in hot-humid climates: An overview. Renew Sust Energ Rev 2018; 82: 1726-36.

[21] Poudyal R, Loskot P, Nepal R, Parajuli R, Khadka SK. Mitigating the current energy crisis in Nepal with renewable energy sources. Renew Sust Energ Rev 2019; 116: 109388.

[22] Cristiano S, Gonella F. Building between environmental boundaries, between need and choice: lowenergy, frugal technologies. Learnings from vernacular solutions - a Sudanese case study. In: Ulgiati S, Vanoli L, Brown MT, Casazza M, Schnitzer H. (2017). BIWAES 2017 - Energy futures, environment and well-being, Graz: Verlag der Technischen Universität Graz; 2017, p. 319-24.

[23] Al-Ghamdi SG, Bilec MM. Green building rating systems and whole-building life cycle assessment: Comparative study of the existing assessment tools. J Archit Eng 2017; 23(1): 040160151-9.

[24] Azhar S. Building information modeling (BIM): Trends, benefits, risks, and challenges for the AEC industry. Leadership Manage Eng; 11(3): 241-52.

[25] Eastman CM, Eastman C, Teicholz P, Sacks R, Liston K. BIM handbook: A guide to building information modeling for owners, managers, designers, engineers and contractors. New York: John Wiley \& Sons; 2011.

[26] Corbett CJ, Muthulingam S. Adoption of Voluntary Environmental Standards: The Role of Signaling and Intrinsic Benefits in the Diffusion of the LEED Green Building Standards, Los Angeles: UCLA: Decisions, Operations, and Technology Management; 2007.

[27] European Commission. Directive 2010/31/EU of the European Parliament and of the Council of 19 May 2010 on the Energy Performance of Buildings; 2010.

[28] Tumminia G, Guarino F, Longo S, Ferraro M, Cellura M, Antonucci. Life cycle energy performances and environmental impacts of a prefabricated building module. Renew Sust Energ Rev 2018; 92: 272-83.

[29] Chae C, Kim S. Subtask 2 Report-A Literature Review, Evaluation of Embodied Energy and $\mathrm{CO}_{2 \mathrm{eq}}$ for Building Construction (Annex 57), Energy in Buildings and Communities Programme, Paris: International Energy Agency; 2016.

[30] Costanza R. Embodied energy and economic valuation. Science 1980; 210(4475): 1219-24.

[31] Thormark C. A low energy building in a life cycle - its embodied energy, energy need for operation and recycling potential. Build Environ 2002; 37(4): 429-35. 
[32] Svizzera Energia. Energia grigia negli edifici nuovi. Guida per gli specialisti del settore delle costruzioni; Ittigen: Svizzera Energia; 2017.

[33] Braham WW. Environmental Building Design: Forms of Emergy. In: Brown MT, Sweeney S, Campbell DE, Huang S, Kang D, Rydberg T, Tilley D, Ulgiati S. Emergy Synthesis 7: Theory and Applications of the Emergy Methodology. Proceedings of the $7^{\text {th }}$ Biennial Emergy Conference. Gainesville: Center for Environmental Policy, University of Florida; 2013, p. 141-46.

[34] Overrated ratings. Nature 2009; 461: 146. https://doi.org/10.1038/461146a

[35] Meadows DH. Thinking in systems: A primer. White River Junction: Chelsea Green Publishing; 2008.

[36] Srinivasan R, Moe K. The Hierarchy of Energy in Architecture: Emergy Analysis. London: Routledge; 2015.

[37] Braham WW. Epigraph. In: Srinivasan R, Moe K. The Hierarchy of Energy in Architecture: Emergy Analysis, London: Routledge; 2015.

[38] Cristiano S. L'approccio sistemico eMergetico. Prospettive per una valutazione integrata della sostenibilità di progetti civili e piani urbani. RIV Rassegna Italiana di Valutazione 2018; 71-72: 149-72.

[39] Haukoos DS. Sustainable architecture and its relationship to industrial building. Master's thesis, Department of Architecture, University of Florida, Gainesville, FL; 1995.

[40] Buranakarn V. Evaluation of recycling and reuse of building materials using the emergy analysis method. PhD dissertation, Department of Architecture, University of Florida, Gainesville, FL; 1998.

[41] Cristiano S. Systemic Assessment for Sustainable Design - LCA-based Emergy Synthesis of an Emergency NGO hospital in Sudan. PhD thesis. Department of Design and Planning in Complex Environments. Università Iuav di Venezia, Venice, Italy; 2018.

[42] Brown MT, Herendeen RA. Embodied energy analysis and EMERGY analysis: a comparative view. Ecol Econ 1996; 19(3): 219-35.

[43] Raugei M, Rugani B, Benetto E, Ingwersen WW. Integrating emergy into LCA: Potential added value and lingering obstacles. Ecol Model 2014; 271: 4-9.

[44] Federici M, Ulgiati S, Verdesca D, Basosi R. Efficiency and sustainability indicators for passenger and commodities transportation systems: The case of Siena, Italy. Ecol Indic 2003; 3(3): 155-69.

[45] Federici M, Ulgiati S, Basosi R. A thermodynamic, environmental and material flow analysis of the Italian highway and railway transport systems. Energy 2008; 33(5): 760-75.

[46] Cristiano S, Gonella F. To build or not to build? Megaprojects, resources, and environment: an emergy synthesis for a systemic evaluation of a major highway expansion. J Clean Prod 2019; 223: 772-89.

[47] Zhou H, Castro-Lacouture D. Integrated ecological assessment of engineering projects based on emergy analysis. Energy Procedia 2016; 88: 160-67.

[48] Meillaud F, Gay JB, Brown MT. Evaluation of a building using the emergy method. Sol Energy 2005; 79(2): 204-12.

[49] Reza B, Sadiq R, Hewage K. Emergy-based life cycle assessment (Em-LCA) of multi-unit and singlefamily residential buildings in Canada. Int J Sustain Built Environ 2014; 3(2): 207-24.

[50] Rothrock H. Sustainable housing: Emergy evaluation of an off-grid residence. Energ Build 2014; 85: $287-$ 92.

[51] Cristiano S, Gonella F. Tecnologie costruttive, limiti ecologici e sostenibilità sistemica. L'analisi emergetica per valutare un progetto edilizio tra Sahara e Sahel. Re-Cycle 2017; 4. Saonara: Il Prato Publishing House [ISSN: 2465-1400]

[52] Brown MT, Buranakarn V. Emergy indices and ratios for sustainable material cycles and recycle options. Resour Conserv and Recy 2003; 38(1): 1-22.

[53] Pulselli RM, Simoncini E, Pulselli FM, Bastianoni S. Emergy analysis of building manufacturing, maintenance and use: Em-building indices to evaluate housing sustainability. Energ Build 2007; 39(5): $620-28$.

[54] Chen W, Liu W, Geng Y, Brown MT, Gao C, Wu R. Recent progress on emergy research: A bibliometric analysis. Renew Sust Energ Rev 2017; 73: 1051-60.

[55] Lu K, Wang H. Estimation of Building's Life Cycle Carbon Emissions Based on Life Cycle Assessment and Building Information Modeling: A Case Study of a Hospital Building in China. J Geosci Environ Protect 2019; 7(6): 147-65.

[56] Lu K, Jiang X, Tam VW, Li M, Wang H, Xia B, Chen Q. Development of a Carbon Emissions Analysis Framework Using Building Information Modeling and Life Cycle Assessment for the Construction of Hospital Projects. Sustainability 2019; 11(22): 6274. 
[57] Ali M, Wang W, Chaudhry N. Application of life cycle assessment for hospital solid waste management: A case study. J Air Waste Manage 2016; 66(10): 1012-18.

[58] Ahmad R, Liu G, Santagata R, Casazza M, Xue J, Khan K, Nawab J, Ulgiati S, Lega M. LCA of hospital solid waste treatment alternatives in a developing country: the case of district Swat, Pakistan. Sustainability 2019; 11(13): 3501.

[59] Ali M, Cristiano S, Geng Y, Gonella F, Ulgiati S. Environmental assessment of Healthcare facilities in the Global South - a case study from Pakistan. [Forthcoming].

[60] Pineo H, Zimmermann N, Davies M. Integrating health into the complex urban planning policy and decision-making context: a systems thinking analysis. Palgrave Commun 2020; 6(1): 1-14.

[61] Cristiano S, Zucaro A, Liu G, Ulgiati S, Gonella F. On the Systemic Features of Urban Systems. A Look at Material Flows and Cultural Dimensions to address Post-growth Resilience and Sustainability. Front Sustain Cities 2020; 2(12): 1-10.

[62] Serrazanetti F. TAMassociati. Taking Care. Architetture con Emergency. Architetti e Architettura, 28. Milano: Electa; 2017.

[63] Dehghani-Sanij AR, Soltani M, Raahemifar K. A new design of wind tower for passive ventilation in buildings to re-duce energy consumption in windy regions. Renewable and Sustainable Energy Reviews 2015; 42: 182-195.

[64] López, M., Rubio, R., Martín, S., \& Croxford, B. (2017). How plants inspire façades. From plants to architecture: Biomimetic principles for the development of adaptive architectural envelopes. Renew Sust Energ Rev 67, 692-703.

[65] Cristiano S, Falchetti C. Vernacular Wisdom as a Path toward Low-energy Eologically Sustainable Housing and Settlements: Participatory Design and Building to Rehabilitate Local Adobe Bricks in E1 Salvador. J World Arch 2019; 4(si1); 889. [https://doi.org/10.26689/jwa.v4isi1.889]

[66] Chandel SS, Sharma V, Marwah BM. Review of energy efficient features in vernacular architecture for improving indoor thermal comfort conditions. Renew Sust Energ Rev 2016; 65: 459-77.

[67] Alegana VA, Maina J, Ouma PO, Macharia PM, Wright J, Atkinson PM, Okiro EA, Snow RW, Tatem AJ. National and sub-national variation in patterns of febrile case management in sub-Saharan Africa. Nat Commun 2018; 9(1): 1-7.

[68] Odum HT. Self-organization, transformity, and information. Science 1988; 242: 1132-39.

[69] Odum HT. Environmental accounting: emergy and environmental decision making. New York: John Wiley and Sons; 1996.

[70] Brown MT, Ulgiati S. Assessing the global environmental sources driving the geobiosphere: A revised emergy baseline. Ecol Model 2016; 339: 126-32.

[71] Brown MT, Ulgiati S. Emergy assessment of global renewable sources. Ecol Model 2016; 339: 148-56.

[72] Shao L, Chen GQ. Renewability assessment of a production system: based on embodied energy as emergy. Renew Sust Energ Rev 2016; 57: 380-92.

[73] Ulgiati S, Brown MT. Labor and services as information carriers in emergy-LCA accounting. J Environ Account Manag 2014; 2(2): 163-70.

[74] Odum HT. Ecological and General Systems: An Introduction to Systems Ecology. Niwot: University Press of Colorado; 1994.

[75] Brown MT, Campbell DE, De Vilbiss C, Ulgiati S. The geobiosphere emergy baseline: a synthesis. Ecol Model 2016; 339: 92-5.

[76] Amaral LP, Martins N, Gouveia JB. A review of emergy theory, its application and latest developments. Renew Sust Energ Rev 2016; 54: 882-8.

[77] Wernet G, Bauer C, Steubing B, Reinhard J, Moreno-Ruiz E, Weidema B. The ecoinvent database version 3 (part I): overview and methodology. Int J Life Cycle Assess 2016; 21(9): 1218-30.

[78] Frischknecht R, Wyss F, Knöpfel SB, Lützkendorf T, Balouktsi M. Cumulative energy demand in LCA: the energy harvested approach. Int J Life Cycle Assess 2015; 20(7): 957-69.

[79] Cristiano S. Systemic Thoughts on Ecology, Society, and Labour. In: Cristiano S. Through the Working Class Ecology and Society Investigated Through the Lens of Labour, Venezia: Ca' Foscari University Press, Venice, Italy; 2018, p. 9-23.

[80] Gonella F, Brocca G, Cristiano S, Khoury N, Salmistraro G, Spagnolo S. When Systemic Sustainability is an Everyday Struggle: An Emergy-Based Analysis of a Dog Shelter. In: Brown MT, Sweeney S, Campbell DE, Huang S, Rydberg T, Ulgiati S. Emergy Synthesis 10: Theory and Applications of the Emergy Methodology. Proceedings of the $10^{\text {th }}$ Biennial Emergy Conference. Gainseville: Center for Environmental Policy, University of Florida, 2019, p. 35-42. 
[81] Boukelia T, Mecibah MS. Parabolic trough solar thermal power plant: Potential, and projects development in Algeria. Renew Sust Energ Rev 2013; 21: 288-97.

[82] Taha H. Urban climates and heat islands; albedo, evapotranspiration, and anthropogenic heat. Energ Build 1997; 25(2): 99-103.

[83] Hamza VM, Vieira FP. Global distribution of the lithosphere-asthenosphere boundary: a new look. Solid Earth 2012; 3(2): 199-212.

[84] Reiter ER. Tropospheric Circulation and Jet Streams. In: Landsberg HE. World Survey of Climatology, Vol. 4, Climate of the Free Atmosphere, Amsterdam: Elsevier; 1969, p. 85-203.

[85] Brown MT, Ulgiati S. A Geobiosphere Baseline for LCA - Emergy Evaluations. In: Brown MT, Sweeney S, Campbell DE, Huang S, Kang D, Rydberg T, Tilley D, Ulgiati S. Emergy Synthesis 7: Theory and Applications of the Emergy Methodology. Proceedings of the $7^{\text {th }}$ Biennial Emergy Conference. Gainesville: Center for Environmental Policy, University of Florida; 2013, p. 481-492.

[86] Miller BI. A study of the filling of Hurricane Donna (1960) over land. Mon Weather Rev 1964; 92(9): 389-406.

[87] Climate Data. Khartoum climate. Khartoum Weather by month / averages, 1982-2012; 2018. https://it.climate-data.org/africa/sudan/al-khartum/khartoum-549/ [accessed 12 April 2020].

[88] De Vilbiss C, Brown MT. New method to compute the emergy of crustal minerals. Ecol Model 2015; 315: 108-15.

[89] Brown MT, Protano G, Ulgiati S. Assessing geobiosphere work of generating global reserves of coal, crude oil, and natural gas. Ecol Model 2011; 222(3): 879-87.

[90] Sweeney S, Cohen MJ, King D, Brown MT. Creation of a Global Emergy Database for Standardized National Emergy Synthesis. In Brown MT, Bardi E, Campbell DE, Huang S, Ortega E, Rydberg T, Tilley D, Ulgiati S. Emergy Synthesis 4. Proceedings of the $4^{\text {th }}$ Biennial Emergy Research Conference, Gainesville: Center for Environmental Policy, University of Florida; 2007, p. 23.1-23.18.

[91] Pan J, Zhang H, Wang X, Liu G. Update Methods of The Global National Environmental Accounting Database (NEAD). J Environ Account Manag 2017; 5(2): 104-15.

[92] Björklund J, Geber U, Rydberg T. Emergy analysis of municipal wastewater treatment and generation of electricity by digestion of sewage sludge. Resour Conserv Recy 2001; 31(4): 293-316.

[93] Odum HT, Collins D. Transformities from Ecosystem Energy Web with the Eigenvalue method. In: Brown MT, Odum HT, Tilley D, Ulgiati S. Emergy Synthesis 2: Proceedings from the Second Biennial Emergy Analysis Research Conference, Gainesville: Center for Environmental Policy, University of Florida; 2003, p. 203-220.

[94] Lou B, Qiu Y, Ulgiati S. Emergy-based indicators of regional environmental sustainability: A case study in Shanwei, Guangdong, China. Ecol Indic 2015; 57: 514-24.

[95] Brown MT, Ulgiati S. Emergy measures of carrying capacity to evaluate economic investments. Popul Environ 2001; 22(5): 471-501.

[96] Wackernagel M, Rees W. Our ecological footprint: reducing human impact on the earth (Vol. 9). Gabriola Island: New Society Publishers; 1998.

[97] Rótolo GC, Francis C, Craviotto RM, Viglia S, Pereyra A, Ulgiati S. Time to re-think the GMO revolution in agriculture. Ecol Inform 2015; 26: 35- 49.

[98] Rótolo GC, Francis C, Craviotto RM, Ulgiati S. Environmental assessment of maize production alternatives: Traditional, intensive and GMO- based cropping patterns. Ecol Indic 2015; 57: 48-60.

[99] Ingwersen WW. Uncertainty characterization for emergy values. Ecol Model 2010; 221(3): 445-52.

[100] Sharifi A. A critical review of selected tools for assessing community resilience. Ecol Indic 2016; 69: 629-47.

[101] Liu Z, Adams M, Cote RP, Geng Y, Ren J, Chen Q, Liu, W, Zhu X. Co-benefits accounting for the implementation of eco-industrial development strategies in the scale of industrial park based on emergy analysis. Renew Sust Energ Rev 2018; 81: 1522-29.

[102] Giunti L, Mercalli L, Poggio A, Ponti M, Tartaglia A, Ulgiati S, Zucchetti M. Economic, Environmental and Energy Assessment of the Turin-Lyon High-Speed Rail. Int J Ecosyst Ecol Sci 2012; 2(4): 361-8.

[103] Zucchetti M, Clerico M, Giunti L, Mercalli L, Poggio A, Ponti M, Tartaglia A, Ulgiati S. The TurinLyon high-speed rail: a technical assessment. Int J Ecosyst Ecol Sci 2017; 7(1): 141-8.

[104] Saad JM, Prochaska JO. A philosophy of health: life as reality, health as a universal value. Palgrave Commun 2020; 6(1): 1-11.

[105] Bonilla-Aldana DK, Dhama K, Rodriguez-Morales AJ. Revisiting the one health approach in the context of COVID-19: a look into the ecology of this emerging disease. Adv Anim Vet Sci 2020; 8(3): 234-7. 
[106] Brown A, Horton R. A planetary health perspective on COVID-19: a call for papers. Lancet 2020; 395(10230): 1099.

[107] Jacobsen KH. Will COVID-19 generate global preparedness?. Lancet 2020; 395(10229): 1013-4.

[108] Odum HT, Odum EC. A prosperous way down: principles and policies. Niwot: University Press of Colorado; 2008. 